\title{
Optical, physical and chemical characteristics of Australian continental aerosols: results from a field experiment
}

\author{
M. Radhi ${ }^{1}$, M. A. Box ${ }^{1}$, G. P. Box ${ }^{1}$, R. M. Mitchell ${ }^{2}$, D. D. Cohen ${ }^{3}$, E. Stelcer ${ }^{3}$, and M. D. Keywood ${ }^{2}$ \\ ${ }^{1}$ School of Physics, University of New South Wales, Sydney NSW 2052, Australia \\ ${ }^{2}$ CSIRO Marine and Atmospheric Research, Centre for Australian Weather and Climate Research, a partnership between \\ CSIRO and the Australian Bureau of Meteorology, Australia \\ ${ }^{3}$ Australian Nuclear Science and Technology Organisation, Menai NSW 2234, Australia
}

Received: 25 August 2009 - Published in Atmos. Chem. Phys. Discuss.: 25 November 2009

Revised: 15 June 2010 - Accepted: 24 June 2010 - Published: 2 July 2010

\begin{abstract}
Mineral dust is one of the major components of the world's aerosol mix, having a number of impacts within the Earth system. However, the climate forcing impact of mineral dust is currently poorly constrained, with even its sign uncertain. As Australian deserts are more reddish than those in the Northern Hemisphere, it is important to better understand the physical, chemical and optical properties of this important aerosol. We have investigated the properties of Australian desert dust at a site in SW Queensland, which is strongly influenced by both dust and biomass burning aerosol.

Three years of ground-based monitoring of spectral optical thickness has provided a statistical picture of gross aerosol properties. The aerosol optical depth data showed a clear though moderate seasonal cycle with an annual mean of $0.06 \pm 0.03$. The Angstrom coefficient showed a stronger cycle, indicating the influence of the winter-spring burning season in Australia's north. AERONET size distributions showed a generally bimodal character, with the coarse mode assumed to be mineral dust, and the fine mode a mixture of fine dust, biomass burning and marine biogenic material.

In November 2006 we undertook a field campaign which collected 4 sets of size-resolved aerosol samples for laboratory analysis - ion beam analysis and ion chromatography. Ion beam analysis was used to determine the elemental composition of all filter samples, although elemental ratios were considered the most reliable output. Scatter plots showed that $\mathrm{Fe}, \mathrm{Al}$ and $\mathrm{Ti}$ were well correlated with $\mathrm{Si}$, and Co reasonably well correlated with $\mathrm{Si}$, with the $\mathrm{Fe} / \mathrm{Al}$ ratio somewhat higher than values reported from Northern Hemisphere sites (as expected). Scatter plots for $\mathrm{Ca}, \mathrm{Mn}$ and $\mathrm{K}$ against $\mathrm{Si}$ showed
\end{abstract}

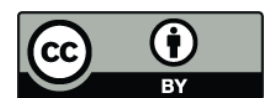

Correspondence to: $\mathrm{M}$. A. Box

(m.box@unsw.edu.au) clear evidence of a second population, which in some cases could be identified with a particular sample day or size fraction. These data may be used to attempt to build a signature of soil in this region of the Australian interior.

Ion chromatography was used to quantify water soluble ions for 2 of our sample sets, complementing the picture provided by ion beam analysis. The strong similarities between the MSA and $\mathrm{SO}_{4}^{2-}$ size distributions argue strongly for a marine origin of much of the $\mathrm{SO}_{4}^{2-}$. The similarity of the $\mathrm{Na}^{+}, \mathrm{Cl}^{-}$and $\mathrm{Mg}^{2+}$ size distributions also argue for a marine contribution. Further, we believe that both $\mathrm{NO}_{3}^{-}$and $\mathrm{NH}_{4}^{+}$ are the result of surface reactions with appropriate gases.

\section{Introduction}

The variability of the optical properties of dust particles depends in large part on the dust source region (Dubovik et al., 2002; Kubilay et al., 2003; Lafon et al., 2006). Therefore physical (size and shape) and chemical (composition and mineralogy) characterization of mineral aerosols from different source regions is important, for a number of reasons. Firstly, dust aerosol exerts a poorly understood forcing on the Earth's radiative budget (Charlson et al., 1992; Tegen et al., 1996; Sokolik et al., 2001; Forster et al., 2007), since it both scatters and absorbs solar radiation, while also absorbing and emitting some infrared radiation. Secondly, dust aerosol may change the physical and radiative properties of clouds (Ramanathan et al., 2001). Thirdly, heterogeneous reactions on the surface of dust particles may lead to the formation of sulfate and/or nitrate layers on the surface of these particles (Prospero and Savoie, 1989; Nishikawa et al., 1991; Dentener et al., 1996; Jacob, 2000). Finally, dust particles may have an impact on human health.

Published by Copernicus Publications on behalf of the European Geosciences Union. 
Global annual dust emission is estimated to be $\sim 1877 \mathrm{Tg} \mathrm{yr}^{-1}$, of which Australia contributes around $5.6 \%$ of the total (Tanaka and Chiba, 2006), and is the greatest contributor of mineral aerosol in the Southern Hemisphere. Further, Australia's deserts are reddish (Bullard and White, 2002), in contrast to the Sahara, for example, which is more yellow. This difference is a reflection of the mineralogy, particularly in relation to iron oxides (Sokolik and Toon, 1996).

The Lake Eyre Basin is a large inland drainage basin receiving little rainfall, with the result that river flows are intermittent. As a consequence, it is the major source of dust from the Australian continent. Mitchell et al. (2010) noted an increase in aerosol loading over Australia's arid interior during the decade 1997-2007, presumably a result of the recent prolonged drought.

Greene et al. (2009) developed a conceptual model that describes the various dust sources and sinks, and the modes of transport of dust materials both into and out of source areas in SE Australia. The model identified key source areas, such as the alluvial and lacustrine environments of the Lake Eyre and Murray-Darling Basins (identified via remote sensing by Bullard et al., 2008). Transport rates and paths for aeolian dust materials across the Australian continent were also outlined. McTainsh (1989) reviewed the role of aeolian dust processes during the Quaternary.

Australian dusts have been found to differ physically from African dusts in consisting of a greater fraction of larger, more highly aggregated particles (Kiefert et al., 1996). Mays et al. (2003) also demonstrated that the aggregates in Australian desert-derived loess (dust) were more stable and resisted dispersion compared to aggregates in glacial-derived loess from the mid-west of the USA. Furthermore, Australian deserts are unique in supporting a much higher level of vegetative cover than Northern Hemisphere deserts, in the form of spinifex (Triodia sp.). This gives rise to the significant fraction of organic matter found in Australian dusts (Boon et al., 1998).

In this study we have monitored the optical properties of aerosol at a desert site for three years, and also conducted a field campaign which involved the collection and analysis of size-resolved aerosol samples for the analysis of their chemical composition. Section 2 describes our sampling location - in the east-central part of the continent, exposed to both desert dust and biomass burning aerosol - and methods used. In Sect. 3 we examine the optical properties of Australian desert aerosol: optical depth, Angstrom exponent and size distribution. In Sect. 4 we present some of the field sampling results: the mass size distributions. Section 5 presents the major elemental analyses. In Sect. 6 we present an analysis of the water-soluble ions, which provides information on secondary aerosol sources. Finally, Sect. 7 contains an overview of the picture these results present.

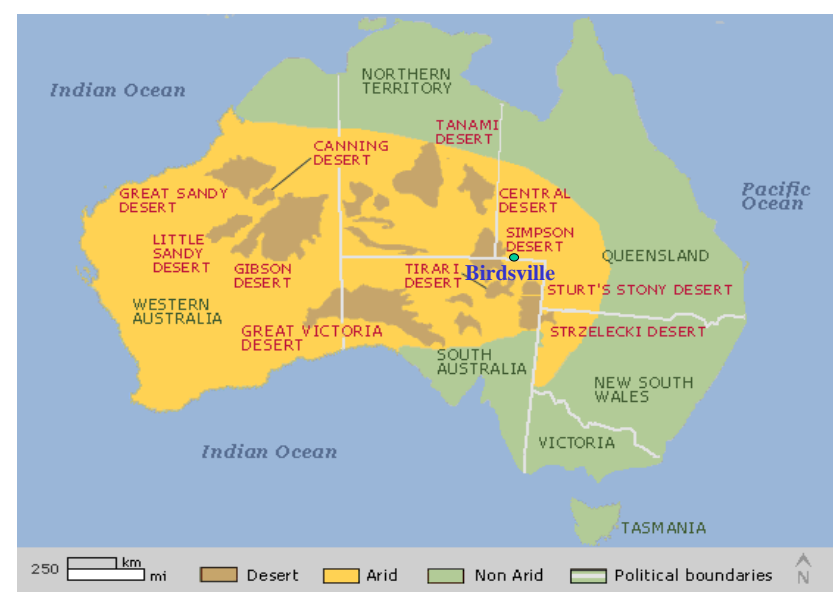

Fig. 1. Map of Australia showing Birdsville location.

\section{Study area and data sources}

\subsection{Field site}

Birdsville, in south-west Queensland $\left(25.90^{\circ} \mathrm{S}, 139.34^{\circ} \mathrm{E}\right.$, 48 m elevation), is a small outback town situated on the banks of the Diamantina River between the sands of the Simpson Desert and the gibbers of Sturt's Stony Desert (Fig. 1), in the heart of the Lake Eyre Basin. Rainfall averages $167 \mathrm{~mm}$ per year, occurring mostly in summer (November-February), with September being the driest month. Daytime temperatures reach $38^{\circ} \mathrm{C}$ in summer. Annual average relative humidity is $48 \%$, with highest values of around $67 \%$ in June. Dust devils are common. The Birdsville permanent population currently stands at approximately 120 , but is augmented at times (especially winter/early spring) by tourism, peaking at around 6000 for the "Birdsville Races" in early September.

\subsection{Aerosol optical depth (AOD) and Angstrom exponent $(\alpha)$}

A Cimel sun photometer at Birdsville has been monitoring aerosol optical depth (AOD) over a range of wavelengths since the spring of 2005. This instrument forms part of the CSIRO Aerosol Ground Station Network (Mitchell and Forgan, 2003), which is affiliated with NASA's global Aerosol Robotic Network, AERONET. Instrument calibration and the generation of AOD and aerosol microphysical data (phase function, size distribution, refractive index and derived quantities such as single scattering albedo and asymmetry parameter) are performed as part of the standard AERONET processing stream (Holben et al., 1998; Dubovik and King, 2000). In this study we will use AOD at $500 \mathrm{~nm}$ as our measure of aerosol loading.

Another parameter which can be extracted from this data is the Angstrom exponent, $\alpha$, which is obtained from a straight line fit of $\ln (\mathrm{AOD})$ vs. $\ln (\lambda)$, over the wavelength 
range 440 to $870 \mathrm{~nm}$. As a good rule-of-thumb, small values of Angstrom exponent are associated with larger particles, while large values are associated with smaller particles, in general.

\subsection{Aerosol samples}

In November 2006, we deployed a 12 stage Micro Orifice Uniform Deposition Impactor (MOUDI) (Marple et al., 1991) to collect size-segregated aerosol particles. The inlet to the MOUDI consisted of two stainless steel bowls with a $2 \mathrm{~cm}$ gap between them to allow air to be sampled equally from all directions, while also protecting against rain. The stage cuts are at 18.0, 10.0, 5.6, 3.2, 1.8, 1.0, 0.56, 0.32, 0.18, 0.1 and $0.056 \mu \mathrm{m}$ aerodynamic diameters, plus an after filter $(<0.056 \mu \mathrm{m})$. In the case of mineral dust particles (the primary, but not the sole component in our samples) with their relatively high density, this is likely to be an overestimate of the effective diameter of an equivalent sphere by around $30 \%$. Note that, because of the range of uncertainties, we have not made this correction to our data at this stage.

These stages allow for collection of samples for the identification of any compositional differences between particles of different size, as the aerosols in many locations are known to be chemically variable, with significant differences between fine and coarse modes. For convenience we define coarse mode aerosols as particles with (aerodynamic) diameters greater than $1.0 \mu \mathrm{m}$, and fine mode aerosols as those with smaller diameters (see also Fig. 6). The flow rate of the MOUDI was $301 / \mathrm{min}$. The collection substrates used on the first 11 stages were polycarbonate Isopore filters $47 \mathrm{~mm}$ in diameter with $0.8 \mu \mathrm{m}$ pore size. The final stage substrate was a Teflon-backed Fluoropore filter $47 \mathrm{~mm}$ in diameter with $1 \mu \mathrm{m}$ pore size.

We weighed the substrates before and after sampling at the Institute for Environmental Research of the Australian Nuclear Science and Technology Organization (ANSTO) using a Mettler Toledo MX5 balance with repeatability 0.0008 $\mathrm{mg}$ at gross load. The temperature during the weighing process was $22 \pm 1.5^{\circ} \mathrm{C}$, and the humidity was $50 \pm 5 \%$. The sum of the masses on all MOUDI filters can be considered a good measurement of Total Suspended Particulates in the atmosphere (TSP) for one sampling period because all particles for different sizes are collected at the one time between the inlet and the after filter stages.

The substrates were analysed using accelerator-based Ion Beam Analysis (IBA) techniques (PIXE and PIGE) at ANSTO (Cohen, 1993; 1998; Cohen et al., 1996). The IBA technique uses an $8 \mathrm{~mm}$ diameter beam of $2.6 \mathrm{MeV}$ protons with 10-15 nA target current. As the spatial distribution of sample on each filter (stage) varied, and the ion beam only sampled the central $10 \%$ of the filter, we have used the IBA results primarily to obtain the ratio of elements to the most abundant element in our dust samples.
Cohen et al. (2002) discuss in detail the minimum detection limits and errors related to PIXE and PIGE measurements. Calibration errors are typically $5 \%$, while experimental measurement errors are typically $10 \%$. Statistical counting errors depend on elemental concentrations. Errors are then added in quadrature. For major elements like $\mathrm{Si}$, Fe etc the final result is likely to be $12 \%$, while for minor elements this could approach $35 \%$.

After IBA, the substrates were analysed for the concentration of soluble ions at CSIRO by suppressed Ion Chromatography (IC). The filters were extracted in $5 \mathrm{ml}$ of MQ-grade water (MQ-grade water is $18 \mathrm{~m} \Omega$ de-ionized water). The sample was then preserved using $1 \%$ chloroform. Anion and cation concentrations were determined by using a Dionex DX500 gradient ion chromatograph. Anions were determined using an AS11 column and an ASRS ultra-suppressor and a gradient eluent of sodium hydroxide. Cations were determined using a CS12 column and a CSRS ultra-suppressor and a methanesulfonate acid eluent. The uncertainty of the soluble ion measurements is $6.6 \%$ at the $95 \%$ confidence level.

\section{Aerosol optical properties}

\subsection{Daily and monthly data}

From plots of the daily and monthly means of AOD for the period August 2005 to June 2008, shown in Fig. 2, we see a seasonal variability in aerosol optical depth. Daily averages of AOD (Fig. 2a) display less variability during winter, reflecting lower wind speed that dominates during this season, resulting in a lack of significant local dust sources. During spring, summer and autumn, the variability in the daily average AOD is increased due to the influence of dust activity, and also biomass burning incursions. Figure $2 b$ shows the monthly means and standard deviations. The annual mean of AOD computed from the monthly means is $0.06 \pm 0.03$.

The daily and monthly means of $\alpha$ are presented in Fig. 3, which shows a very clear seasonal cycle, along with large variation in daily measurements, including negative values on some days - and especially during summer and early autumn - which is likely due to dust storm activity. (Inadequate cloud screening is unlikely to be a factor.) Higher values in AOD along with a wide range of $\alpha$ values during spring months is suggestive of a contribution from a different aerosol type such as regional biomass burning, and/or long range (intercontinental) transport (Rosen, et al., 2000; Gloudemans et al., 2006), and/or the possible influence of marine biogenic emission when the air mass is advected from the ocean. Mt Isa, the largest point source of $\mathrm{SO}_{2}$ in the Southern Hemisphere, is $550 \mathrm{~km}$ due north: while direct advection would be uncommon, some contribution is likely. The situation is more complex during winter months, when low AOD values are associated with high $\alpha$ values. 


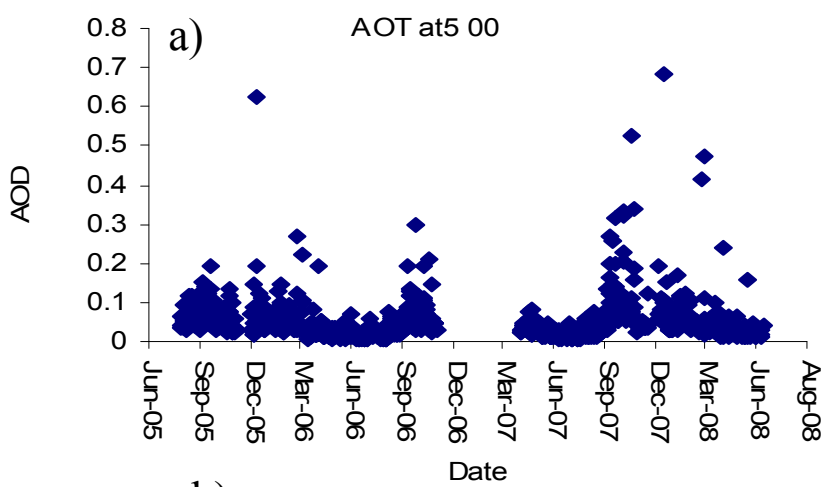

b)

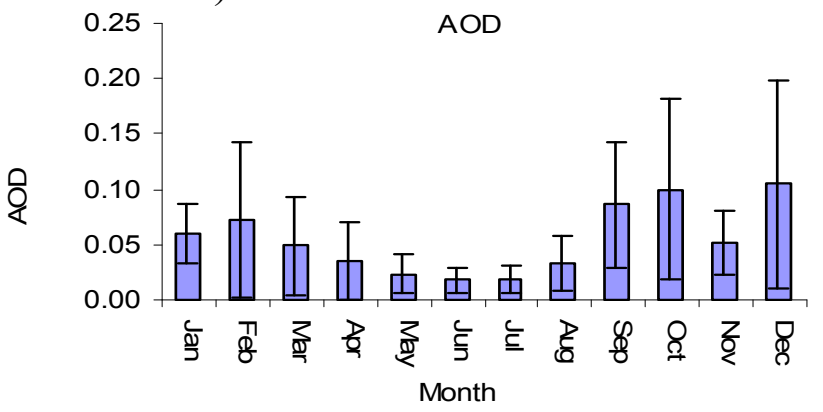

Fig. 2. (a) Daily means of AOD at $500 \mathrm{~nm}$ from August 2005-June 2008. (b) Monthly means and standard deviations of AOD for same period.

A scatter plot of daily average Angstrom exponent, $\alpha$, against daily average AOD at $500 \mathrm{~nm}$, is presented in Fig. 4a. This figure shows a wide range of $\alpha$ associated with AOD less than 0.03 . To isolate the low AOD measurements, we plotted the time series of all AOD $<0.03$ in Fig. 4b, which shows that nearly all of these measurements were during late autumn and winter. As a check, we re-plotted the time series of $\alpha$, excluding all data where AOD was less than 0.02: the seasonal cycle was still obvious.

Winter is the dry season, characterized by clear skies, along with lowest temperatures and wind speeds. It is also the burning season in the 'top end' of northern of Australia, so that a biomass burning signature from that region at our Birdsville instrument is likely, whenever the winds are from an appropriate direction. (In addition, winter is a tourism season, when many people are camping under the stars and using firewood for cooking and heating, which produces biomass burning aerosol, although only in very small amounts).

It should also be noted that the uncertainty in $\alpha$ increases significantly whenever it is computed from AOD data less than 0.02. For this reason, we did not use AOD data below 0.02 when computing $\alpha$ because of the high probability of unacceptable errors.

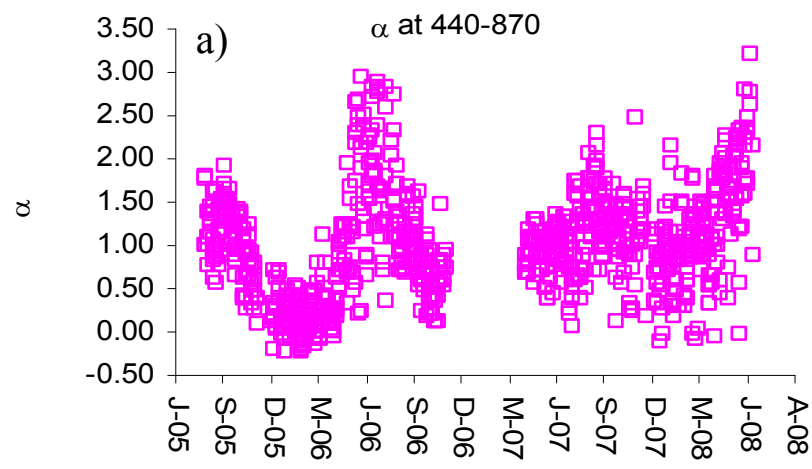

Date

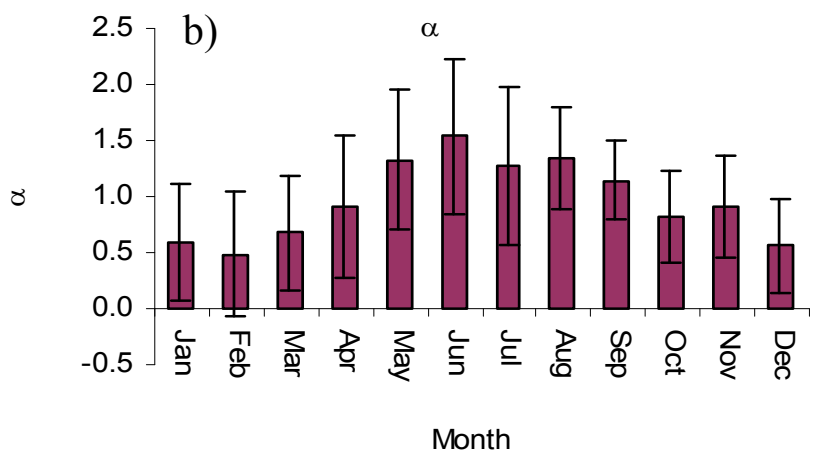

Fig. 3. (a) Daily means of $\alpha(440-870 \mathrm{~nm})$ from August 2005-June 2008. (b) Monthly means and standard deviations of $\alpha$ for same period.

\subsection{Seasonal statistics}

The seasonal frequency distributions of daily means of AOD and $\alpha$ are presented in Fig. 5. The left panel shows that the AOD distribution was very narrow during autumn and winter, with $\sim 60 \%$ of the data observed in the 0.03 bin in both seasons. During summer the distribution was broader and the peak was in the 0.05 bin which accounted for $\sim 40 \%$ of the data observed, with around $20 \%$ of the data observed in each of the two adjoining bins. The spring distribution was very broad again peaking in the 0.05 bin, but with a long tail, with around $40 \%$ of the data above 0.08 . Overall around $80 \%$ of daily AOD means are below 0.1, a clear indication of low pollution levels. Around $80 \%$ are less than 0.06 during autumn and winter months, but only $50 \%$ fall in that range during spring and summer.

The frequency distributions of daily means of $\alpha$ - central panel - were broad in all seasons, indicative of a range of particle sizes entering the atmosphere, or a range of atmospheric processing. This figure shows a skewed distribution during summer with approximately half the data observed in the lowest two bins, which indicates that coarse mode particles predominate. During autumn the peak was shifted to the 1.1 and 1.4 bins, which accounted for $\sim 40 \%$ of the total daily means, while around $30 \%$ of the daily means were 


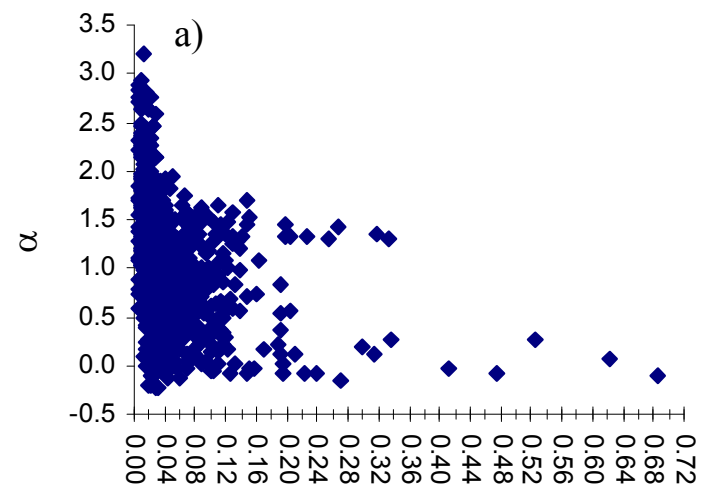

$A O D$

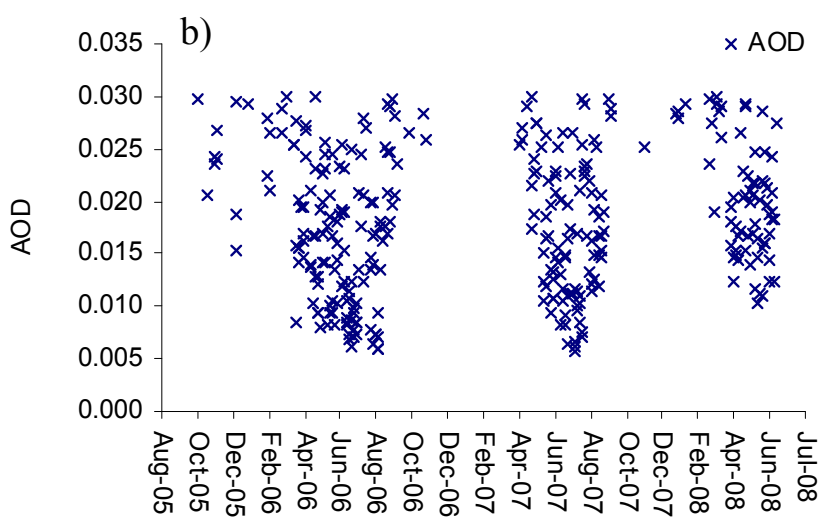

Fig. 4. (a) Scatter plot of daily means of $\alpha(440-870 \mathrm{~nm})$ vs. daily means of AOD. (b) Daily means of AOD less than 0.03 .

in the 0.2 and 0.5 bins. The winter pattern showed a normal distribution with around $65 \%$ of the data in the $0.7-1.6$ range. This indicates that fine mode particles predominate during this season, a result of local wood burning and regional biomass burning, plus (presumably) fine dust particles. The spring distribution was approximately normal, with around $65 \%$ of the data in the $0.7-1.6$ range, which again implies both fine mode biomass burning aerosol (plus, presumably, fine dust) and a contribution from a different aerosol type, such as coarse dust. The annual mean of $\alpha$ computed from the monthly means is $0.9 \pm 0.3$.

Scatter plots of daily average $\alpha$ vs. AOD for each season in Fig. 5 (right panel) show that during all seasons a wide range of $\alpha$ is associated with AOD less than 0.05. On the other hand, the $\alpha$ values generally decreased (including some negative values) as the value of AOD increased beyond 0.1 in all seasons, which implies that dust is the main contributor to the higher optical thickness values during those seasons. However, the spring pattern shows a second aerosol signature with larger $\alpha$ values contributing to the larger optical thickness measurements, indicating the influence of fine mode parti- cles, most likely biomass burning aerosol transported from the north.

\subsection{Aerosol size distribution}

We used the daily average (columnar) volume size distributions from the AERONET web site to calculate seasonal average volume size distributions: these are presented in Fig. 6a. This graph shows a clear bimodal pattern in all seasons, as well as some significant differences. Summer and spring have the largest aerosol loadings, with a coarse mode peak at $3.5 \mu \mathrm{m}$ radius. The spring distribution shows the strongest fine mode, with a peak between 0.10 and $0.15 \mu \mathrm{m}$ radius, which is further evidence of a second aerosol contribution (most likely biomass burning) during this season. The autumn and winter distributions show lower total aerosol content, with the coarse mode again dominating. While some inversions may be biased as a consequence of the low AOD values, especially in winter, these distributions are consistent with those from Africa studied by Reid et al. (2003), and from Arabia by Eck et al. (2008).

Figure $6 \mathrm{~b}$ shows the volume size distributions for selected days during spring 2007, and we see that the coarse mode peak shifts from day to day. On 8 October 2007 the fine mode peak was dominant, and the air mass back trajectory during this day shows advection from the north, where hot spot satellite imagery confirmed that biomass burning was occurring (as expected for this time of year).

Qin and Mitchell (2009) have performed a cluster analysis of AERONET retrievals from a number of Australian sites ( 3 in northern Australia subject to biomass burning, 2 desert sites, plus others), including Birdsville. This yielded 4 classes which they identify as aged smoke, fresh smoke, coarse dust, and a super-absorptive class of undetermined nature. While all 4 classes have bimodal size distributions, it is only the coarse dust class which has a dominant coarse mode (and a very small fine mode). In Fig. 6c we show Qin and Mitchell's (2009) size distributions for their aged smoke ("class0"), and coarse dust ("class2") classes (with appropriate normalization). The similarity with the fine and coarse modes, respectively, of the distributions shown in Fig. $6 \mathrm{~b}$ is striking, giving added confidence to our interpretation of these retrievals.

The aerosol size distribution over Birdsville is clearly bimodal: a fine mode which we believe is primarily biomass burning "aged smoke" (probably with some fine dust), and a coarse mode which we believe is primarily mineral dust. The contributions of each vary seasonally in ways that are quite predictable. The fine mode occurs mainly in spring, the peak of the biomass burning season in northern Australia. The coarse mode strength is primarily dictated by wind speeds, which are stronger in spring and summer. 
Table 1. Sampling details.

\begin{tabular}{|c|c|c|c|c|c|}
\hline & & \multicolumn{4}{|c|}{ Collection } \\
\hline & & $\mathrm{B}$ & $\mathrm{C}$ & $\mathrm{D}$ & $\mathrm{E}$ \\
\hline \multirow[t]{2}{*}{ Start } & data & 01/11/06 & 02/11/06 & 03/11/06 & 05/11/06 \\
\hline & time & 9:10 a.m. & 4:00 p.m. & 5:00 p.m. & 6:00 p.m. \\
\hline \multirow[t]{3}{*}{ Finish } & data & 02/11/06 & 03/11/06 & 05/11/06 & 07/11/06 \\
\hline & time & 9:10 a.m. & 4:00 p.m. & 5:00 p.m. & 6:00 a.m. \\
\hline & Total Hours & 24 & 24 & 48 & 36 \\
\hline Wind & Median & 3.8 & 5.7 & 3.3 & 3.9 \\
\hline speed & $\operatorname{Max}$ & 9.9 & 8.2 & 5.7 & 6.3 \\
\hline $\mathrm{m} / \mathrm{s}^{2}$ & Min & 1.1 & 2.6 & 1.1 & 0.9 \\
\hline Wind Direction & Median & $65.3^{\circ}$ & $182.2^{\circ}$ & $156.0^{\circ}$ & $148.5^{\circ}$ \\
\hline \multicolumn{2}{|c|}{ Dust conditions } & $\begin{array}{l}\text { Dust devils active } \\
\text { during the } \\
\text { sampling time but no } \\
\text { dust storm }\end{array}$ & $\begin{array}{l}\text { High wind during } \\
\text { the sampling time, } \\
\text { with brief local dust } \\
\text { storm }\end{array}$ & $\begin{array}{l}\text { Calm wind during } \\
\text { the sampling time, } \\
\text { with occasional dust } \\
\text { devils }\end{array}$ & $\begin{array}{l}\text { Calm wind during } \\
\text { the sampling time, } \\
\text { with occasional } \\
\text { dust devils }\end{array}$ \\
\hline
\end{tabular}
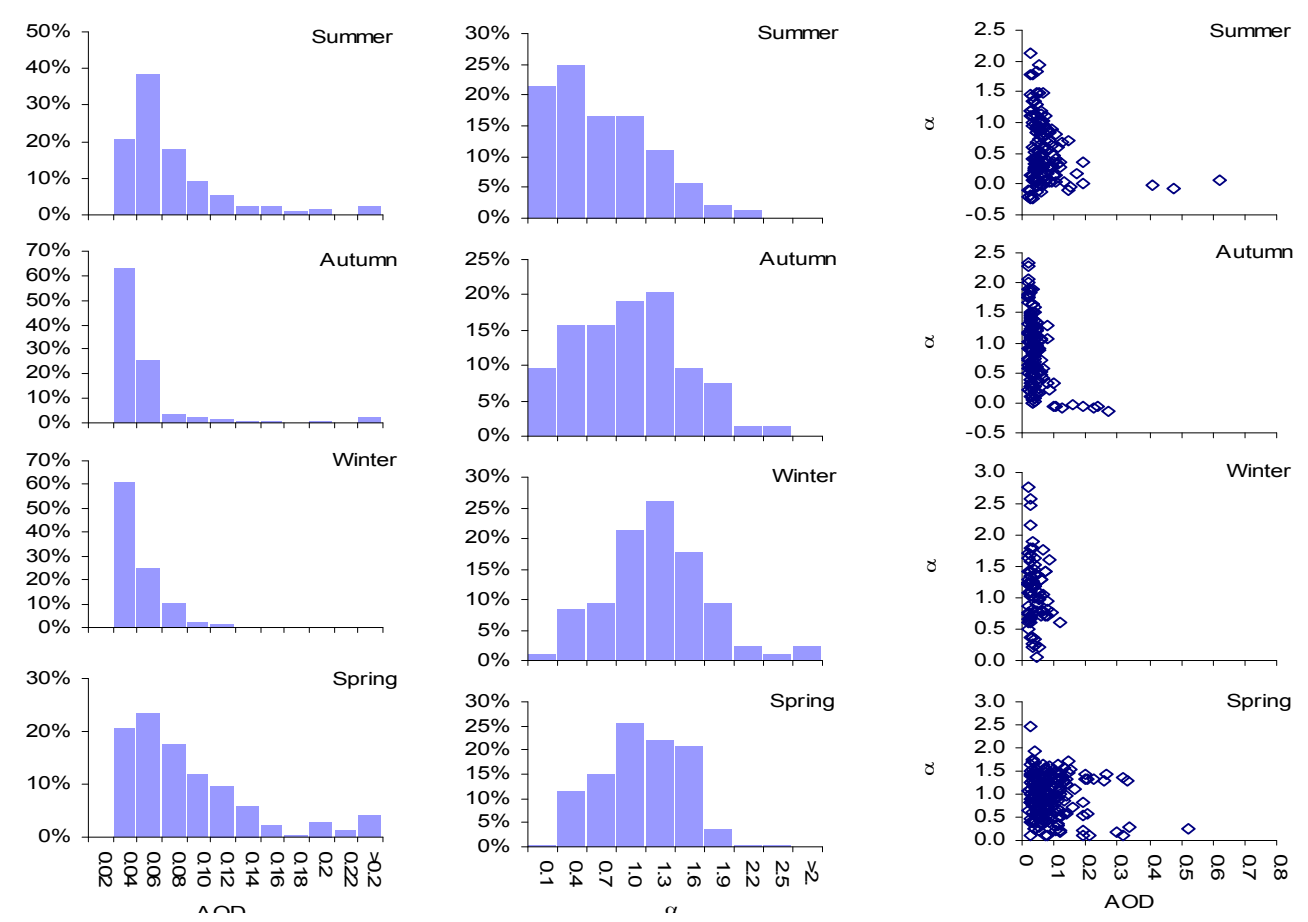

Fig. 5. Left panel: Seasonal frequency distributions of daily mean AOD. Central panel: Seasonal frequency distributions of daily mean $\alpha$. Right panel: Seasonal scatter plots of daily mean $\alpha$ vs. daily mean AOD.

\section{Aerosol samples: gravimetric mass distributions}

In November 2006 we deployed a 12 stage Micro Orifice Uniform Deposition Impactor (MOUDI) to collect sizesegregated aerosol particles. During this field campaign we collected 5 sets of samples - denoted A, B, C, D and E. Sample set A was used for equipment testing only, and has not been included in the analysis. Table 1 gives the start and finish times of our sampling periods, as well as relevant environmental information. (Back trajectories are considered below.) Note that collection times varied, depending on dust activity.

The size-resolved mass concentrations for different data sets are presented in Fig. 7, which shows that the size 

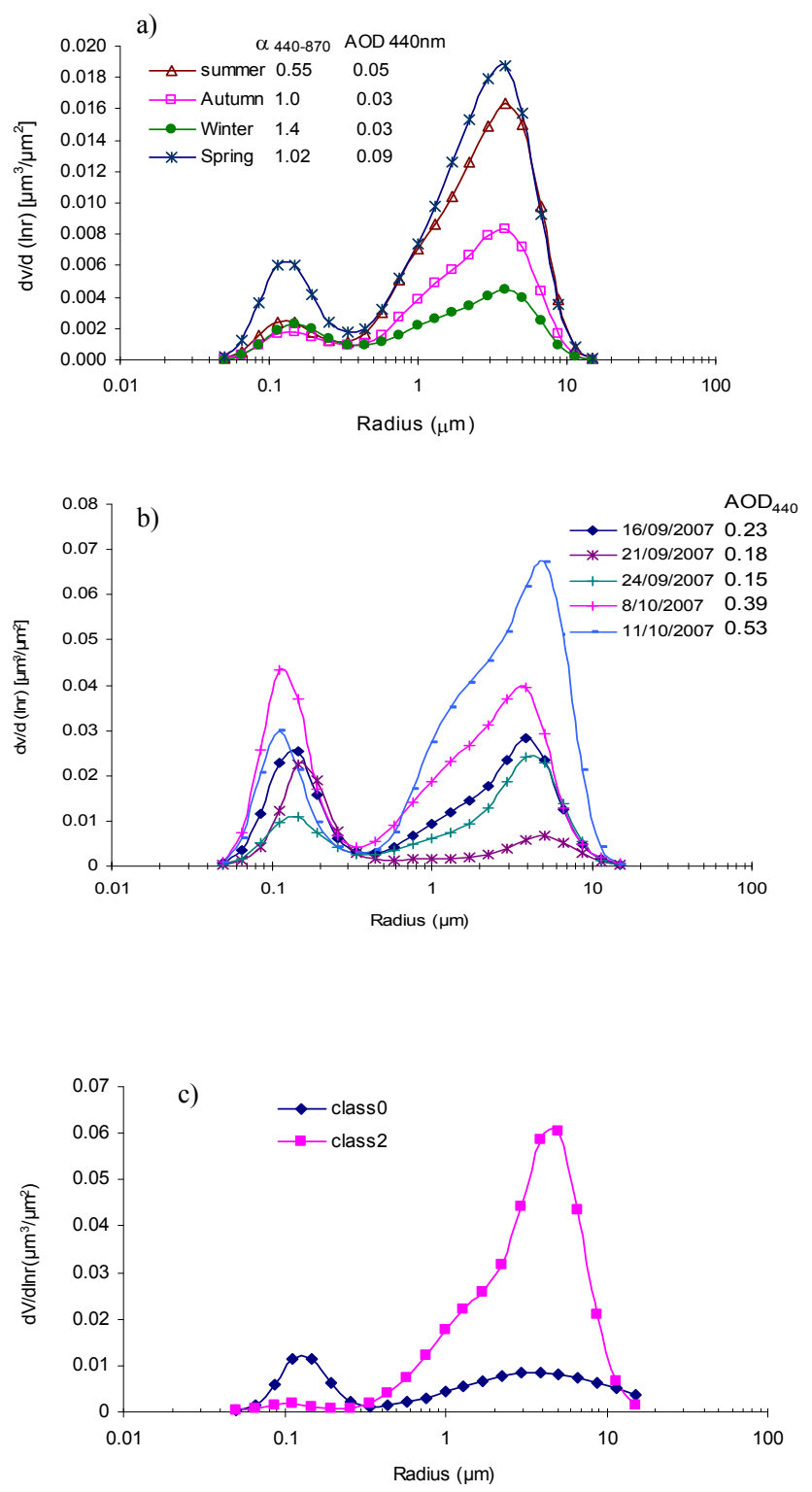

Fig. 6. (a) Seasonal average volume size distributions. (b) Daily average volume size distributions for selected days. (c) Qin and Mitchell (2009) class 0 and class 2 size distributions.

spectrum was quite variable during our field campaign. Total suspended particulates (TSP) during the sampling period are in order $\mathrm{C}>\mathrm{B}>\mathrm{E}>\mathrm{D}$ : see Table 2. The mass concentration was significantly higher during periods $B$ and $C$ due to the influence of moderate to high wind speeds and local dust activity on those days (see Table 1).

During sampling period B there was significant raised dust, although not associated with a dust storm. (Dust devils may have contributed to this.) The mass size distribution during this period was essentially bimodal, but with a doubled coarse mode peak. During period C, a weak local dust storm occurred (but for a few moments only). The resulting size
Table 2. Mass fractions.

\begin{tabular}{llllll}
\hline & $\mathrm{B}$ & $\mathrm{C}$ & $\mathrm{D}$ & $\mathrm{E}$ & Average \\
$\mathrm{TSP} \mu \mathrm{g} / \mathrm{m}^{3}$ & 57.2 & 107.5 & 17.5 & 28.8 & \\
$\mathrm{PM}_{1} 0 / \mathrm{TSP}$ & $73 \%$ & $78 \%$ & $80 \%$ & $72 \%$ & $76 \% \pm 4$ \\
$\mathrm{PM}_{2.5} / \mathrm{TSP}$ & $42 \%$ & $44 \%$ & $53 \%$ & $47 \%$ & $46 \% \pm 5$ \\
$\mathrm{PM}_{1} / \mathrm{TSP}$ & $32 \%$ & $27 \%$ & $32 \%$ & $34 \%$ & $31 \% \pm 3$ \\
$\mathrm{PM}_{2.5} / \mathrm{PM}_{1} 0$ & $58 \%$ & $57 \%$ & $66 \%$ & $65 \%$ & $61 \% \pm 5$ \\
$\mathrm{PM}_{1} / \mathrm{PM}_{1} 0$ & $44 \%$ & $35 \%$ & $40 \%$ & $47 \%$ & $41 \% \pm 5$ \\
$\mathrm{PM}_{1} / \mathrm{PM}_{2.5}$ & $76 \%$ & $62 \%$ & $60 \%$ & $73 \%$ & $68 \% \pm 8$ \\
\hline
\end{tabular}

distribution was tri-modal with peaks at $0.18,0.56 \mu \mathrm{m}$ diameter, and a broad coarse mode peak. During the other sampling periods the distributions were relatively flat. We applied a smoothing/inversion procedure to these 4 data sets (Keywood et al., 1999), and the results are presented in Fig. 7b. From these retrievals we are able to extract the masses in key size ranges (see below).

Table 2 shows the ratios between $\mathrm{PM}_{10}, \mathrm{PM}_{2.5}, \mathrm{PM}_{1}$ and TSP; $\mathrm{PM}_{2.5}, \mathrm{PM}_{1}$ and $\mathrm{PM}_{10}$; and $\mathrm{PM}_{2.5}$ and $\mathrm{PM}_{1}$. ("PMn" is "particulate matter with diameters less than $n \mu m$ ".) On average the $\mathrm{PM}_{10}, \mathrm{PM}_{2.5}$ and $\mathrm{PM}_{1}$ components make up 76\%, $46 \%$ and $31 \%$ of TSP respectively. $\mathrm{PM}_{2.5}$ and $\mathrm{PM}_{1}$ comprise $61 \%$ and $41 \%$ of $\mathrm{PM}_{10}$ respectively, and $\mathrm{PM}_{1}$ makes up $68 \%$ of $\mathrm{PM}_{2.5}$. From the above analysis we can conclude that the $\mathrm{PM}_{2.5}$ component (sometimes taken as the fine mode for air quality purposes) accounts for approximately $50 \%$ of all particulate mass in the Birdsville atmosphere at this time of year. Using our definition of $1.0 \mu \mathrm{m}$ diameter as the boundary, however, gives a coarse/fine ratio of around 2.0. The coarser particles are, of course, more rapidly removed by gravitation.

AERONET retrievals were available on two of these days, and particularly sampling period $\mathrm{C}$, which gave the most clearly defined modal distribution. In Figure $7 \mathrm{c}$ we replot our inverted distribution for this period, along with the AERONET retrieval. Several factors may explain the differences, particularly for sizes above $10 \mu \mathrm{m}$. Firstly our results are for the surface only while AERONET is a column retrieval (hence the different units): the larger particles are likely to be found only in the lowest atmospheric layers. Secondly our results are based on a $24 \mathrm{~h}$ sampling period. Thirdly, AERONET inversions are likely to be less reliable due the higher error level associated with the low optical depths involved (at least on non-dusty days). Finally, Weinzierl et al. (2008) have questioned the reliability of AERONET retrievals in this size range, given that the longest measurement wavelength is only $1.02 \mu \mathrm{m}$, although this topic is controversial (e.g., Reid et al., 2003). In particular, the comparison shown in Fig. 7c suggests that the AERONET inversion leads to an artificially steep decline on the large particle side of the coarse mode peak, an issue discussed by Qin and Mitchell (2009). Given these caveats, and 

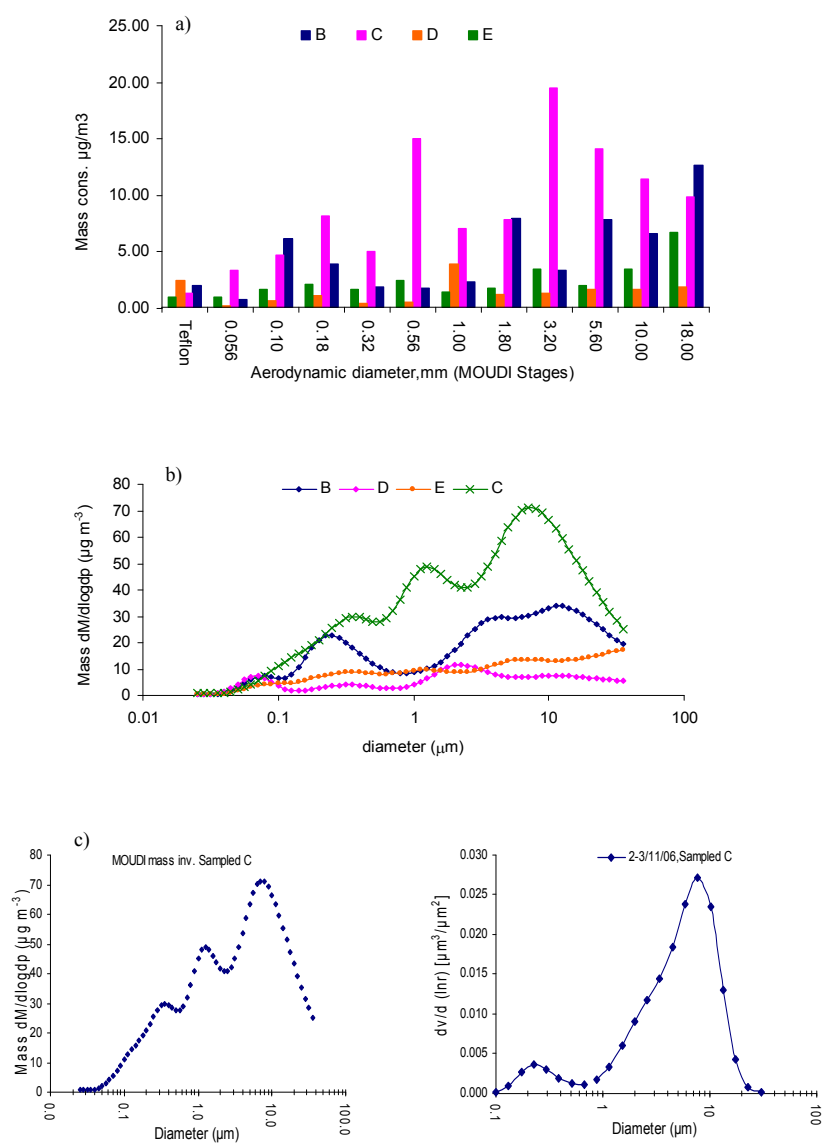

Fig. 7. (a) Size resolved mass concentrations for all 4 samples. (b) Smoothed size distributions. (c) Comparison of MOUDI size distribution with AERONET retrieval for sample $\mathrm{C}$.

the errors associated with both approaches, we consider the agreement to be as good as could be expected.

\section{Elemental composition and source apportionment}

Ion Beam Analysis showed that, as expected, $\mathrm{Si}$ is an abundant element in all size fractions, and is used in this study as a dust 'indicator' for Australian desert aerosol. We used the elemental concentrations determined through the IBA to calculate the mass ratio of elements to $\mathrm{Si}$ : these ratios are summarised in Table 3, along with the mass ratios of these elements in the Earth's crust from CRC Handbook (Lide, 1997). Size-resolved mass ratios for selected elements are presented in Fig. 8. Scatter plots for some of these elements, based on all 48 data values, are presented in Fig. 9. We classified the elements into two groups: crustal elements (e.g. Al, $\mathrm{Fe}, \mathrm{Ca}$, $\mathrm{K}, \mathrm{Mn}, \mathrm{Ti}, \mathrm{Co}, \mathrm{Cu}$ and $\mathrm{Zn}$ ); and $\mathrm{Na}$ and $\mathrm{Cl}$.
Table 3. Ratio of elements to $\mathrm{Si}$.

\begin{tabular}{llllll}
\hline Element & \multicolumn{5}{l}{ Ratio/Si } \\
\hline & $\mathrm{B}$ & $\mathrm{C}$ & $\mathrm{D}$ & $\mathrm{E}$ & Crust* \\
$\mathrm{Na}$ & $8.63 \mathrm{E}-02$ & $7.14 \mathrm{E}-02$ & $3.80 \mathrm{E}-01$ & $1.77 \mathrm{E}-01$ & $8.37 \mathrm{E}-02$ \\
$\mathrm{Al}$ & $2.71 \mathrm{E}-01$ & $2.92 \mathrm{E}-01$ & $2.73 \mathrm{E}-01$ & $2.71 \mathrm{E}-01$ & $2.92 \mathrm{E}-01$ \\
$\mathrm{P}$ & $1.18 \mathrm{E}-02$ & $4.36 \mathrm{E}-03$ & $2.03 \mathrm{E}-02$ & $3.56 \mathrm{E}-02$ & $3.72 \mathrm{E}-03$ \\
$\mathrm{Cl}$ & $5.54 \mathrm{E}-02$ & $2.69 \mathrm{E}-02$ & $3.70 \mathrm{E}-01$ & $1.48 \mathrm{E}-01$ & $5.14 \mathrm{E}-04$ \\
$\mathrm{~K}$ & $6.18 \mathrm{E}-02$ & $5.49 \mathrm{E}-02$ & $5.24 \mathrm{E}-02$ & $4.75 \mathrm{E}-02$ & $7.41 \mathrm{E}-02$ \\
$\mathrm{Ca}$ & $3.06 \mathrm{E}-02$ & $3.20 \mathrm{E}-02$ & $5.91 \mathrm{E}-02$ & $4.39 \mathrm{E}-02$ & $1.47 \mathrm{E}-01$ \\
$\mathrm{Ti}$ & $2.23 \mathrm{E}-02$ & $2.55 \mathrm{E}-02$ & $1.81 \mathrm{E}-02$ & $1.87 \mathrm{E}-02$ & $2.00 \mathrm{E}-02$ \\
$\mathrm{Cr}$ & $7.36 \mathrm{E}-03$ & $3.37 \mathrm{E}-03$ & $1.25 \mathrm{E}-02$ & $1.27 \mathrm{E}-02$ & $3.62 \mathrm{E}-04$ \\
$\mathrm{Mn}$ & $3.77 \mathrm{E}-03$ & $3.68 \mathrm{E}-03$ & $4.77 \mathrm{E}-03$ & $4.61 \mathrm{E}-03$ & $3.37 \mathrm{E}-03$ \\
$\mathrm{Fe}$ & $2.15 \mathrm{E}-01$ & $2.25 \mathrm{E}-01$ & $2.32 \mathrm{E}-01$ & $2.28 \mathrm{E}-01$ & $2.00 \mathrm{E}-01$ \\
$\mathrm{Co}$ & $1.42 \mathrm{E}-03$ & $1.30 \mathrm{E}-03$ & $1.22 \mathrm{E}-03$ & $1.54 \mathrm{E}-03$ & $8.87 \mathrm{E}-05$ \\
$\mathrm{Ni}$ & $9.71 \mathrm{E}-03$ & $4.17 \mathrm{E}-03$ & $1.75 \mathrm{E}-02$ & $1.98 \mathrm{E}-02$ & $2.98 \mathrm{E}-04$ \\
$\mathrm{Cu}$ & $1.92 \mathrm{E}-03$ & $9.89 \mathrm{E}-04$ & $1.66 \mathrm{E}-03$ & $1.54 \mathrm{E}-03$ & $2.13 \mathrm{E}-04$ \\
$\mathrm{Zn}$ & $1.30 \mathrm{E}-03$ & $8.96 \mathrm{E}-04$ & $1.55 \mathrm{E}-03$ & $1.82 \mathrm{E}-03$ & $2.48 \mathrm{E}-04$ \\
$\mathrm{Br}$ & $3.09 \mathrm{E}-03$ & $1.45 \mathrm{E}-03$ & $6.88 \mathrm{E}-03$ & $4.89 \mathrm{E}-03$ & $8.51 \mathrm{E}-06$ \\
$\mathrm{~Pb}$ & $3.22 \mathrm{E}-03$ & $1.02 \mathrm{E}-03$ & $1.89 \mathrm{E}-03$ & $2.23 \mathrm{E}-03$ & $5.32 \mathrm{E}-08$ \\
\hline
\end{tabular}

* Crust ratio computed from (Lide, 1997).

\subsection{Crustal elements}

The TSP Fe/Si ratios are in the range 0.215-0.232, which is moderately higher than the value in the Earth's crust: this most probably reflects the high amount of Fe which occurs naturally in Australian desert soil. The $\mathrm{Fe} / \mathrm{Si}$ mass ratios for all samples are shown in Fig. 8, which shows a complex structure, reasonably consistent across all four samples. The scatter plot of $\mathrm{Fe}$ against $\mathrm{Si}$ in Fig. 9a shows an excellent linear relationship with $R^{2}=0.98$, indicating that soil is the source of $\mathrm{Fe}$ in our samples. This ratio of $\mathrm{Fe}$ to $\mathrm{Si}$ may be used to build a signature for soil/dust in this region of Australia.

The TSP Al/Si mass ratios are in the range $0.271-0.292$, close to the value in the Earth's crust, and the scatter plot of $\mathrm{Al}$ against $\mathrm{Si}$ in Fig. 9a again shows an excellent linear relationship with $R^{2}=0.99$. The TSP Ti/Si mass ratios were between 0.018 and 0.026 , which is in good agreement with the crustal value. The scatter plot of Ti against $\mathrm{Si}$ again shows an excellent linear relationship with $R^{2}=0.97$. Both of these ratios can be incorporated into our regional soil signature.

The TSP Ca/Si mass ratios are lower than the value in the Earth's crust by $\sim 60-80 \%$ for all samples. The scatter plot of $\mathrm{Ca}$ against $\mathrm{Si}$ appears to show two populations, indicative of two sources. The primary population displays an excellent linear relationship with $R^{2}=0.97$, so that this population can be assumed to be associated with Si in Australian soil. The second population comprised particles between 1.8 and $10.0 \mu \mathrm{m}$, and from samples D and E only. This population also shows a reasonable correlation with $\mathrm{Si}$, with $R^{2}=0.73$, suggesting a non-free $\mathrm{Ca}$ source such as gypsum mineral. Back trajectories suggest the air mass reaching the sampling 

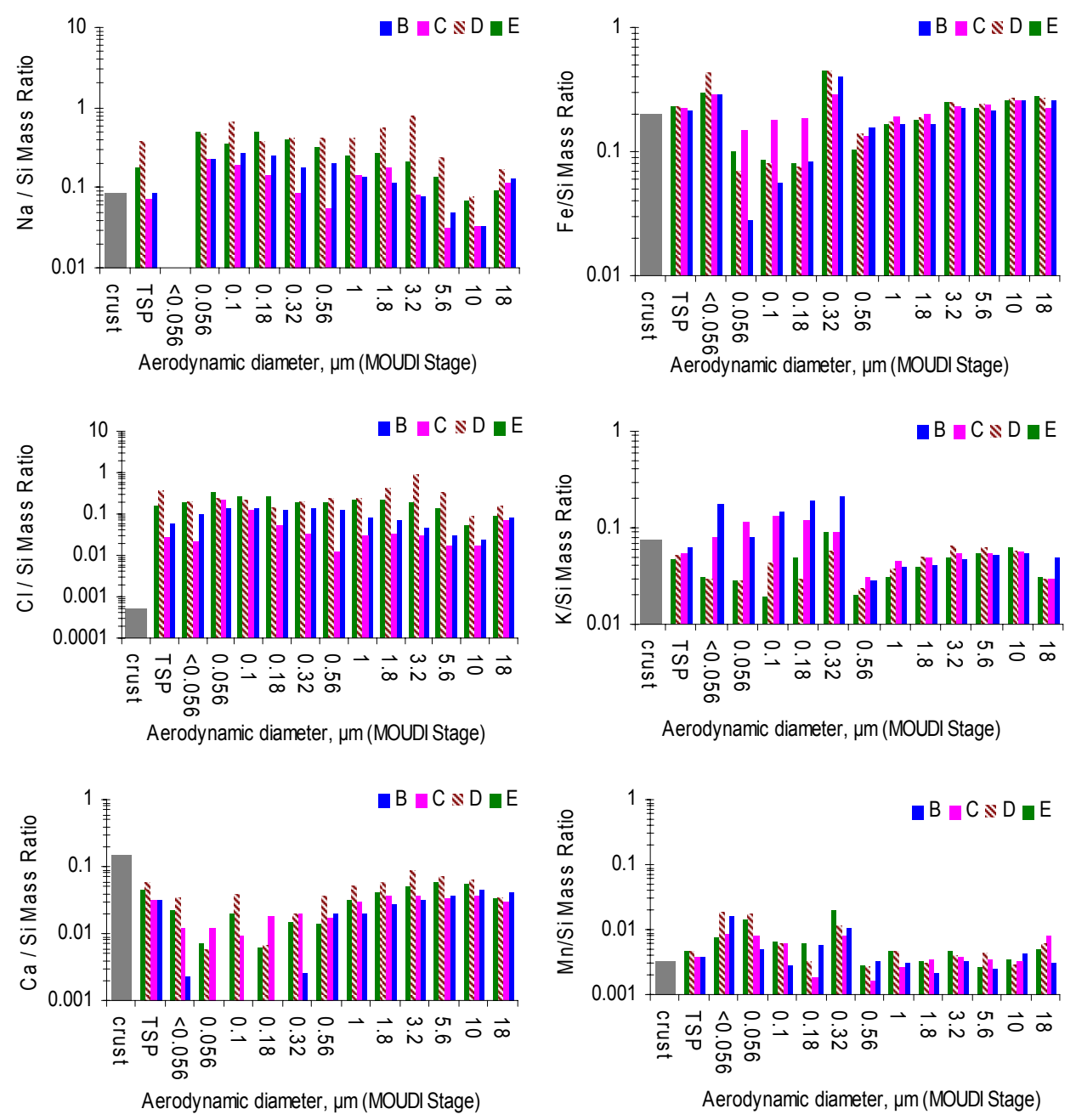

Fig. 8. Size-resolved mass ratios of some elements to Si for all samples.

site had travelled over gypsum mines during sampling periods D and E (see Fig. 10).

The TSP Mn/Si mass ratios are greater than the Earth's crustal values by $33-66 \%$, and Fig. 8 shows that the higher mass ratios occurred mainly in the size range $0.32 \mu \mathrm{m}$ and below. Moreover the scatter plot of Mn against Si appears to show two populations: the dominant population, showing an excellent linear relationship with $R^{2}=0.94$, can be assumed to be associated with $\mathrm{Si}$ in Australian soil. The second population shows a poor relationship with $\mathrm{Si}$, and all points were from the size range below $1.8 \mu \mathrm{m}$, and from all samples.

The scatter plot of K against Si again shows two populations, indicative of two sources. The dominant population shows an excellent linear relationship with $R^{2}=0.98$, and is again clearly associated with $\mathrm{Si}$ in Australian soil. The second population points are in the fine range, $0.32 \mu \mathrm{m}$ and smaller, and from the B and C samples only. They showed no correlation with $\mathrm{Si}$, indicating an unrelated source: most likely biomass burning/smoke, or similar.
Figure $9 \mathrm{~b}$ shows scatter plots of $\mathrm{Co}, \mathrm{Cu}$ and $\mathrm{Zn}$ against $\mathrm{Si}$ : these plots show less correlation. For these elements, possible statistical variability of the low values obtained may be masking a modest relationship to $\mathrm{Si}$.

\section{$5.2 \mathrm{Na}$ and $\mathrm{Cl}$}

The TSP mass ratios of $\mathrm{Na} / \mathrm{Si}$ are in good agreement with the values in the Earth's crust during sampling periods B and C, but are high during sampling periods $\mathrm{D}$ and $\mathrm{E}$, suggesting the contribution of other aerosol sources such as sea spray. Backtrajectories for the 4 days, shown in Fig. 10, show that during periods D and $\mathrm{E}$ the air was advected from the Southern Ocean. Furthermore, the size-resolved mass ratios in Fig. 8 show that the $\mathrm{Na} / \mathrm{Si}$ mass ratio is very high in most sizes during periods $\mathrm{D}$ and $\mathrm{E}$, however this ratio is larger in the fine fraction during periods $\mathrm{B}$ and $\mathrm{C}$. Table 3 shows that the ratio of $\mathrm{Cl}$ to $\mathrm{Si}$ is very high during all events, with the coarse fraction ratio at $3.2 \mu \mathrm{m}$ diameter (Fig. 8 ) being especially high 
a)
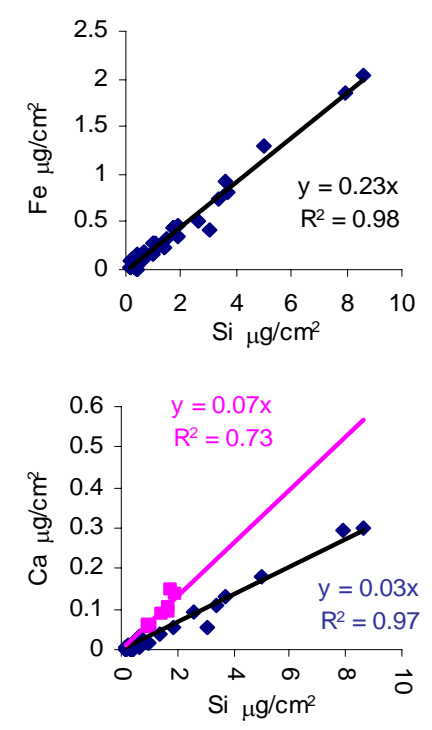

b)

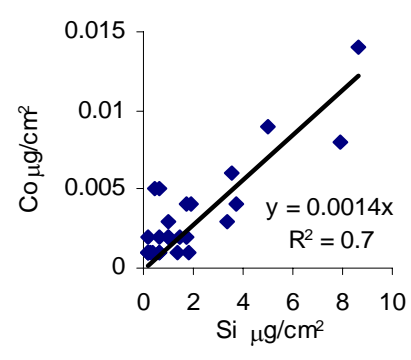

c)

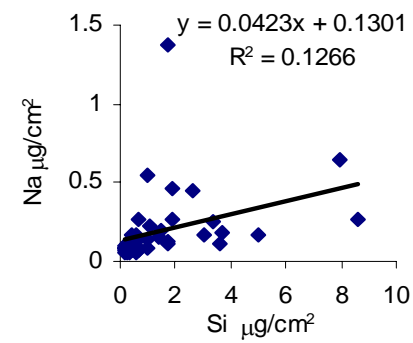

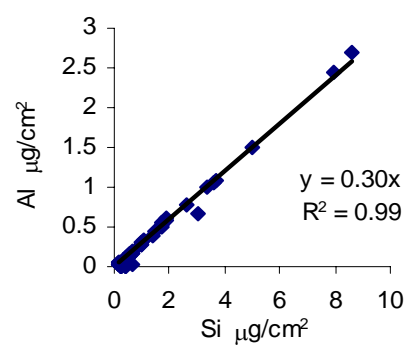
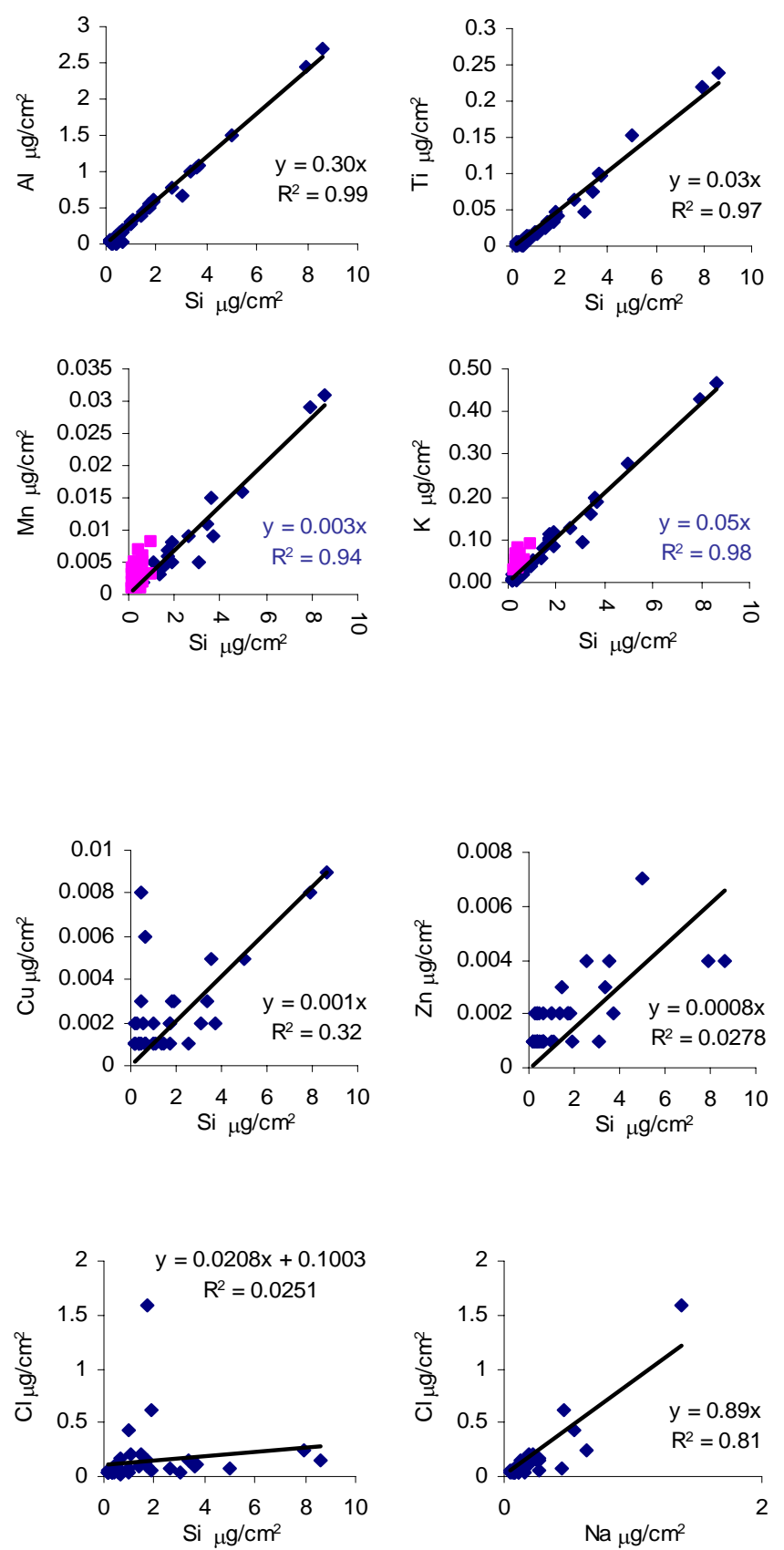

Fig. 9. (a) Scatter plots of $\mathrm{Fe}, \mathrm{Ti}, \mathrm{Al}, \mathrm{Ca}, \mathrm{Mn}$ and $\mathrm{K}$ against $\mathrm{Si}$. (b) Scatter plots of $\mathrm{Co}, \mathrm{Cu}$ and $\mathrm{Zn}$ against $\mathrm{Si}$. (c) Scatter plots of $\mathrm{Na}$ and $\mathrm{Cl}$ against $\mathrm{Si}$, and $\mathrm{Cl}$ against $\mathrm{Na}$.

during period $\mathrm{D}$. As a result, the $\mathrm{Cl} / \mathrm{Na}$ mass ratio was 0.65 , $0.38,0.98$ and 0.84 during sample periods $\mathrm{B}, \mathrm{C}, \mathrm{D}$ and $\mathrm{E}$ respectively, which is very much higher than the value of 0.006 in the Earth's crust, but closer to (though still lower than) the value of 1.8 in seawater.
Figure 9c shows scatter plots of $\mathrm{Na}$ and $\mathrm{Cl}$ against $\mathrm{Si}$, and also a scatter plot of $\mathrm{Cl}$ against $\mathrm{Na}$. The scatter plot of $\mathrm{Cl}$ against $\mathrm{Na}$ shows a reasonable linear relationship with $R^{2}=0.81$. High $\mathrm{Cl} / \mathrm{Na}$ ratios during periods $\mathrm{D}$ and $\mathrm{E}$ are clearly due to some combination of influences of sea spray aerosols from the ocean (see Figure 10) and salt from Australia's dry lakes (southwest of Birdsville). The high value of 

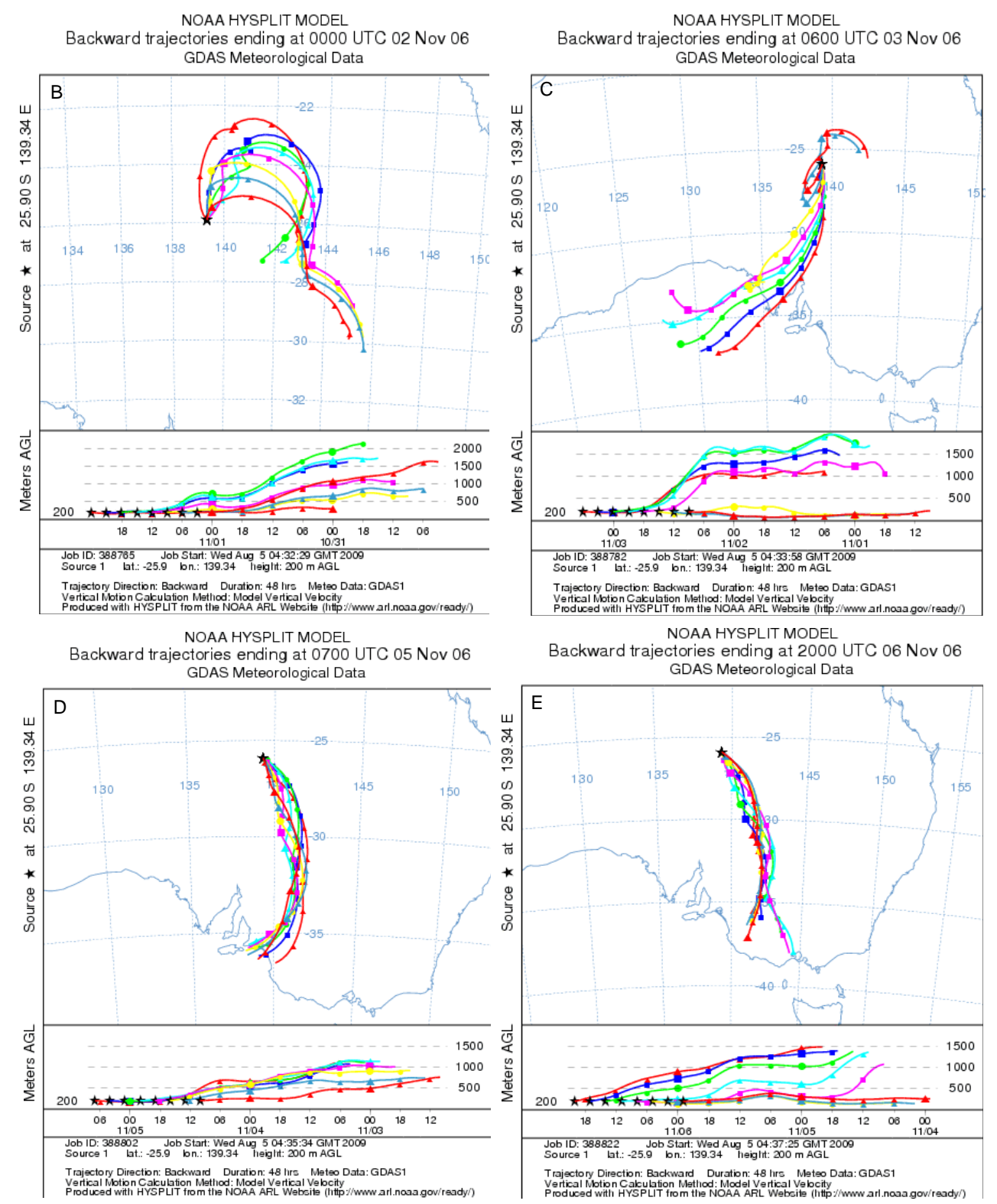

Fig. 10. Back-trajectories during aerosol sampling days.

$\mathrm{Cl}$ may relate to the high amount of dry salt (halite, $\mathrm{NaCl}$ ) from dry lakes in the Australian arid region, mixed with desert dust aerosol.

\section{Water-soluble ions}

The concentration of total, and coarse (1.0-18 $\mu \mathrm{m}$ range) ion species found in sample periods $\mathrm{C}$ and $\mathrm{E}$ are presented in Table 4 . The size distributions of important ions are presented in Fig. 11.

$\mathrm{SO}_{4}^{2-}, \mathrm{Ca}^{2+}$ and $\mathrm{K}^{+}$ions are found in sea spray aerosol and also in soil, and fine mode $\mathrm{K}^{+}$may be found in biomass burning aerosol. We removed the sea spray component from the concentration of these ions by using the following definitions:

$$
\begin{aligned}
& \mathrm{nssSO}_{4}^{2-}=\mathrm{SO}_{4}^{2-}-\mathrm{Na}^{+}\left(\mathrm{SO}_{4}^{2-} / \mathrm{Na}^{+}\right)_{\text {seawater }} \\
& \mathrm{nssCa}^{2+}=\mathrm{Ca}^{2+}-\mathrm{Na}^{+}\left(\mathrm{Ca}^{2+} / \mathrm{Na}^{+}\right)_{\text {seawater }} \\
& \mathrm{nssK}^{+}=\mathrm{K}^{+}-\mathrm{Na}^{+}\left(\mathrm{K}^{+} / \mathrm{Na}^{+}\right)_{\text {seawater }}
\end{aligned}
$$

where $\left(\mathrm{SO}_{4}^{2-} / \mathrm{Na}^{+}\right)_{\text {seawater }}, \quad\left(\mathrm{Ca}^{2+} / \mathrm{Na}^{+}\right)_{\text {seawater }}$ and $\left(\mathrm{K}^{+} / \mathrm{Na}^{+}\right)_{\text {seawater }}$ are the mass ratios of $\mathrm{SO}_{4}^{2-}, \mathrm{Ca}^{2+}$ and $\mathrm{K}^{+}$in seawater, and we used values from Millero and Sohn (1992). 

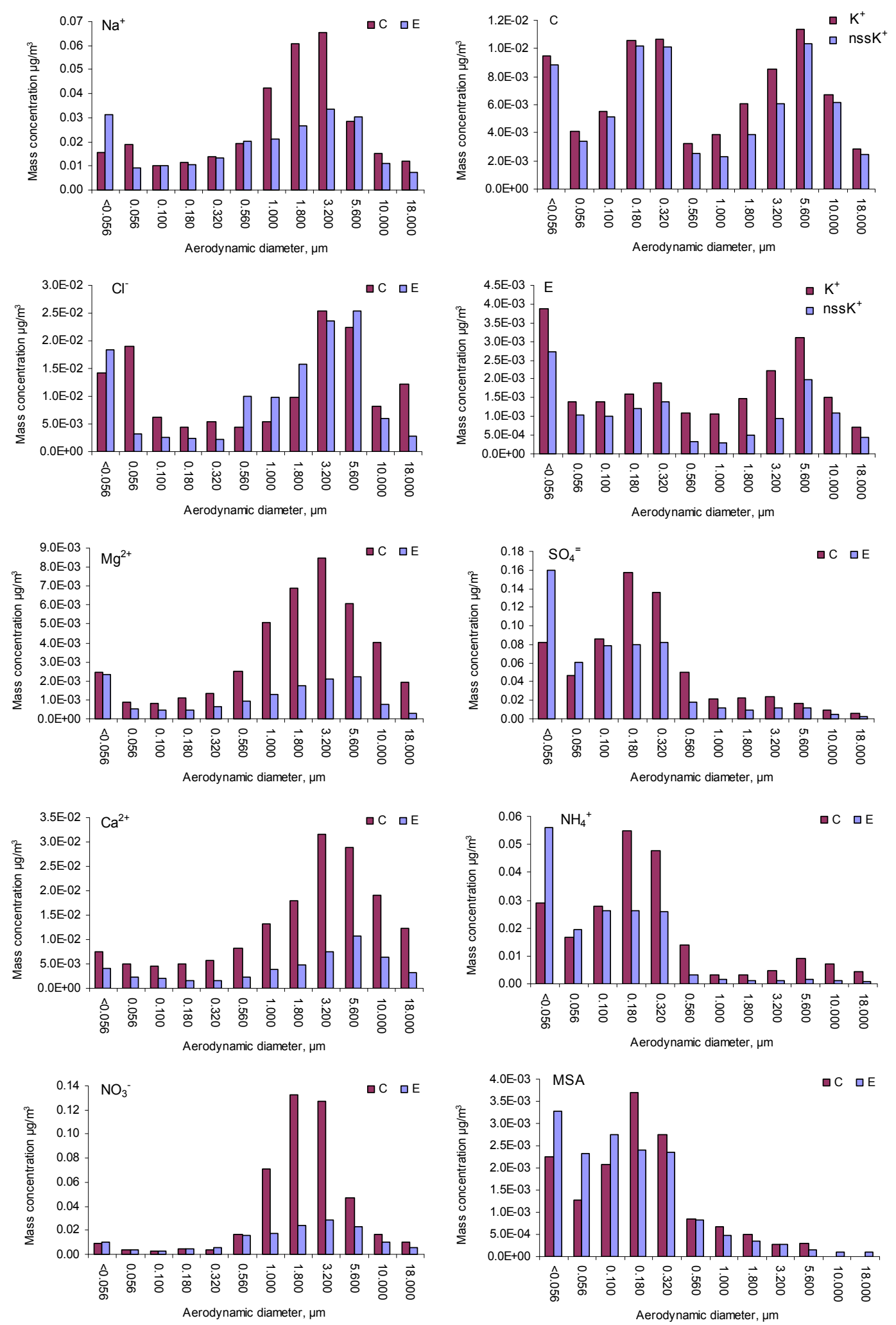

Fig. 11. Size-resolved concentrations of major water-soluble ionic species during sampling periods $C$ and $E$. 


\section{1 $\mathrm{Na}^{+}, \mathrm{Cl}^{-}$and $\mathrm{Mg}^{2+}$}

Figure 11 shows that $\mathrm{Na}^{+}$is predominantly in the coarse mode during period $\mathrm{C}$, with a broad peak in the 1.0-3.2 $\mu \mathrm{m}$ range, while during period $\mathrm{E}$ this peak shifted to the 3.2$5.6 \mu \mathrm{m}$ range. A secondary peak is found in the ultra-fine range during both periods. The total concentration of this ion was 0.314 and $0.225 \mu \mathrm{g} / \mathrm{m}^{3}$ for periods $\mathrm{C}$ and $\mathrm{E}$, respectively, with the coarse fraction predominating with $78 \%$ and $58 \%$, respectively. The size distribution of $\mathrm{Cl}^{-}$was bimodal for both periods, the first peak occurring in the coarse mode in the 3.2-5.6 $\mu \mathrm{m}$ range for both samples, and a secondary peak in the ultra-fine range. The total concentration of $\mathrm{Cl}^{-}$was 0.137 and $0.122 \mu \mathrm{g} / \mathrm{m}^{3}$, with $61 \%$ and $68 \%$ in the coarse fraction, for periods $\mathrm{C}$ and $\mathrm{E}$, respectively. The $\mathrm{Cl}^{-} / \mathrm{Na}^{+}$mass ratios were 0.44 and 0.54 , which is lower than the value in seawater, although greater than the value in the Earth's crust. Sodium chloride may react with nitric acid gas (see Reaction $\mathrm{R} 4$ below) to deplete the chlorine concentration, and thus reduce the $\mathrm{Cl}^{-} / \mathrm{Na}^{+}$mass ratio.

We see from Fig. 11 that $\mathrm{Mg}^{2+}$ was found predominantly in the coarse mode for both periods $\mathrm{C}$ and $\mathrm{E}$. The size distribution of this ion has a broad peak centred at $3.2 \mu \mathrm{m}$ for pe$\operatorname{riod} \mathrm{C}$ and at 3.2-5.6 $\mu \mathrm{m}$ during period $\mathrm{E}$. The total concentration of $\mathrm{Mg}^{2+}$ was 0.042 and $0.014 \mu \mathrm{g} / \mathrm{m}^{3}$ during periods $\mathrm{C}$ and $\mathrm{E}$, respectively, with the coarse fraction containing $78 \%$ and $61 \%$ respectively (Table 4 ). $\mathrm{Mg}^{2+}$ is present in mineral dust and sea salt. However, the mass ratios of $\mathrm{Mg}^{2+} / \mathrm{Na}^{+}$are in good agreement with the seawater ratio in all size fractions during period $\mathrm{C}$, indicating the primary influence of sea spray on this ion. However, this ratio was significantly reduced during period $\mathrm{E}$, a consequence of the longer time spent over land as seen in Fig. 10.

\section{2 $\mathrm{Ca}^{2+}$}

We see from Fig. 11 that $\mathrm{Ca}^{2+}$ was found primarily in the coarse mode, with a predominant peak in the 3.2-5.6 $\mu \mathrm{m}$ range for period $\mathrm{C}$, and at $5.6 \mu \mathrm{m}$ for period $\mathrm{E}$. (This shift in peak may be a reflection of the second population identified in Sect. 5.1; Fig. 9a.) The total concentration of $\mathrm{Ca}^{2+}$ was $0.16 \mu \mathrm{g} / \mathrm{m}^{3}$ during period $\mathrm{C}$, but this reduced sharply during period $\mathrm{E}$ to only $0.05 \mu \mathrm{g} / \mathrm{m}^{3}$, with $77 \%$ and $72 \%$, respectively, in the coarse mode. (These results are consistent with the overall higher mass concentrations during period $\mathrm{C}$ - see Fig. 7 - resulting from the local dust storm.)

The TSP mass ratios of $\mathrm{Ca}^{2+} / \mathrm{Na}^{+}$were much higher than the ratio in sea water (Table 4) during those periods, which indicates that most of the calcium originated from dust particles. Calcium is found in sea salt and in crustal material, including insoluble silicates, weakly soluble calcite $\left(\mathrm{CaCO}_{3}\right)$ and moderately soluble gypsum $\left(\mathrm{CaSO}_{4}\right)$. We removed the seawater component from total $\mathrm{Ca}^{2+}$ using Reaction (R2), and found that $92 \%$ and $83 \%$ of the total $\mathrm{Ca}^{2+}$ was $\mathrm{nsSCa}^{2+}$ during periods $\mathrm{C}$ and $\mathrm{E}$, respectively. The size distributions of $\mathrm{nssCa}^{2+}$ are very similar to the $\mathrm{Ca}^{2+}$ patterns for both samples.

\section{$6.3 \mathrm{NO}_{3}^{-}$}

It is clear from Figure 11 that the $\mathrm{NO}_{3}^{-}$in our samples was concentrated in the lower coarse mode region, with a distribution similar to the $\mathrm{Na}^{+}, \mathrm{Ca}^{2+}$ and $\mathrm{Mg}^{2+}$ distributions. The concentrations of $\mathrm{NO}_{3}^{-}$are found to be $91 \%$ and $72 \%$ in the coarse fraction during periods $\mathrm{C}$ and $\mathrm{E}$, respectively. When $\mathrm{NaCl}$ particles are present in the atmosphere, coarse mode $\mathrm{NO}_{3}^{-}$may be produced as a result of the reaction of $\mathrm{HNO}_{3}$ with $\mathrm{NaCl}$ to produce $\mathrm{NaNO}_{3}$ and $\mathrm{HCl}$ (Wall et al., 1988; Zhuang et al., 1999):

$\mathrm{HNO}_{3}+\mathrm{NaCl} \rightarrow \mathrm{NaNO}_{3}+\mathrm{HCl}$

Studies by Savoie and Prospero (1982), Harrison and Pio (1983) and John et al. (1990) report that coarse mode nitrate is dominant in coastal regions, whereas the fine mode is dominant in rural areas. We note from Fig. 11 that the $\mathrm{Cl}^{-} / \mathrm{Na}^{+}$ mass ratio is especially low in the $1.8 \mu \mathrm{m}$ bin in period $\mathrm{C}$, which corresponds to the nitrate peak.

$\mathrm{HNO}_{3}$ may also react with $\mathrm{Ca}$ and $\mathrm{Mg}$ carbonates on soil particles to generate coarse mode soluble nitrates via the reaction (Wolf, 1984; Dasch and Cadle, 1990; Mamane and Gottlieb, 1992; Pakkanen et al., 1996):

$2 \mathrm{HNO}_{3}+\mathrm{CaCO}_{3} \rightarrow \mathrm{Ca}\left(\mathrm{NO}_{3}\right)_{2}+\mathrm{H}_{2} \mathrm{O}+\mathrm{CO}_{2}$

In summary, we have found that desert dust from this region of Australia appears to be well mixed with $\mathrm{NaCl}$ as a result of salt-rich dry lakes in the Australian arid zone (see Sects. 6 and 6.1). The reaction of $\mathrm{HNO}_{3}$ on dust particles and/or dry $\mathrm{NaCl}$ is a possible mechanism for the formation of (soluble) nitrates in the coarse ranges seen in Fig. 11.

\section{$6.4 \mathrm{~K}^{+}$}

The sources of $\mathrm{K}^{+}$may be soil (including crustal salts), sea spray or biomass burning aerosol. The size distribution of $\mathrm{K}^{+}$was multi-modal, though without an easily definable "structure" for both periods. However, the additional peak at $0.18-0.32 \mu \mathrm{m}$ in period $\mathrm{C}$ is fully consistent with the second population noted in Sect. 5.1. The total concentrations of $\mathrm{K}^{+}$were 0.083 and $0.021 \mu \mathrm{g} / \mathrm{m}^{3}$, with $52 \%$ and $53 \%$ present in the fine mode of the $\mathrm{C}$ and $\mathrm{E}$ samples, respectively.

Air mass back trajectories in Fig. 10 show that during both sampling periods the air was advected from the Southern Ocean (although there was some advection from the north during period $\mathrm{C}$ ): we therefore removed the sea spray component from the total concentration of $\mathrm{K}^{+}$by using Reaction (R3), and found that $86 \%$ and $61 \%$ of the total $\mathrm{K}^{+}$was $\mathrm{nssK}^{+}$during periods $\mathrm{C}$ and $\mathrm{E}$, respectively. We may note that the coarse mode of $\mathrm{nssK}^{+}$was strongly depleted in the $1.0-5.6 \mu \mathrm{m}$ range relative to total $\mathrm{K}^{+}$peak during period $\mathrm{C}$, 
Table 4. Ionic species concentrations of all ions detected in Ion Chromatography analysis, with the mass ratios of these ions to $\mathrm{Na}^{+}(\mathrm{Coarse}$ fraction is the sum of species concentrations found at stages $\geq 1.0 \mu \mathrm{m}$.)

\begin{tabular}{|c|c|c|c|c|c|c|c|}
\hline & \multicolumn{3}{|c|}{ C Sample } & \multicolumn{3}{|c|}{ E Sample } & \multirow{3}{*}{$\begin{array}{l}\text { Ion } / \mathrm{Na}^{+} \\
\text {in sea water }\end{array}$} \\
\hline & \multicolumn{2}{|c|}{ Concentration, $\mu \mathrm{g} / \mathrm{m}^{3}$} & \multirow{2}{*}{$\begin{array}{l}\text { TSP } \\
\text { Ion/ } \mathrm{Na}^{+}\end{array}$} & \multicolumn{2}{|c|}{ Concentration, $\mu \mathrm{g} / \mathrm{m}^{3}$} & \multirow{2}{*}{$\begin{array}{l}\text { TSP } \\
\text { Ion/ } \mathrm{Na}^{+}\end{array}$} & \\
\hline & TSP & Coarse & & TSP & Coarse & & \\
\hline $\mathrm{Na}^{+}$ & 3.14E-01 & 2.24E-01 & $1.00 \mathrm{E}+00$ & $2.25 \mathrm{E}-01$ & $1.30 \mathrm{E}-01$ & $1.00 \mathrm{E}+00$ & $1.00 \mathrm{E}+00$ \\
\hline $\mathrm{NH}_{4}^{+}$ & 2.22E-01 & $3.22 \mathrm{E}-02$ & 7.08E-01 & $1.64 \mathrm{E}-01$ & $7.45 \mathrm{E}-03$ & 7.31E-01 & - \\
\hline $\mathrm{K}^{+}$ & 8.30E-02 & 3.94E-02 & $2.65 \mathrm{E}-01$ & 2.13E-02 & $1.01 \mathrm{E}-02$ & $9.48 \mathrm{E}-02$ & $3.71 \mathrm{E}-02$ \\
\hline $\mathrm{Mg}^{2+}$ & $4.16 \mathrm{E}-02$ & $3.24 \mathrm{E}-02$ & $1.33 \mathrm{E}-01$ & $1.38 \mathrm{E}-02$ & $8.46 \mathrm{E}-03$ & $6.16 \mathrm{E}-02$ & $1.20 \mathrm{E}-01$ \\
\hline $\mathrm{Ca}^{2+}$ & $1.59 \mathrm{E}-01$ & $1.23 \mathrm{E}-01$ & $5.07 \mathrm{E}-01$ & $5.02 \mathrm{E}-02$ & $3.63 \mathrm{E}-02$ & 2.23E-01 & $3.82 \mathrm{E}-02$ \\
\hline $\mathrm{CI}^{-}$ & $1.37 \mathrm{E}-01$ & 8.36E-02 & 4.37E-01 & $1.22 \mathrm{E}-01$ & 8.35E-02 & $5.43 \mathrm{E}-01$ & $1.80 \mathrm{E}+00$ \\
\hline $\mathrm{NO}_{2}^{-}$ & $1.13 \mathrm{E}-02$ & $6.04 \mathrm{E}-03$ & $3.59 \mathrm{E}-02$ & $7.57 \mathrm{E}-03$ & $5.67 \mathrm{E}-03$ & 3.37E-02 & - \\
\hline $\mathrm{NO}_{3}^{-}$ & 4.45E-01 & 4.04E-01 & $1.42 \mathrm{E}+00$ & $1.51 \mathrm{E}-01$ & $1.09 \mathrm{E}-01$ & $6.70 \mathrm{E}-01$ & - \\
\hline $\mathrm{SO}_{4}^{2-}$ & $6.59 \mathrm{E}-01$ & $9.98 \mathrm{E}-02$ & $2.10 \mathrm{E}+00$ & 5.34E-01 & $5.28 \mathrm{E}-02$ & $2.37 \mathrm{E}+00$ & $2.52 \mathrm{E}-01$ \\
\hline $\mathrm{C}_{2} \mathrm{O}_{4}^{2-}$ & 7.91E-02 & 4.71E-02 & $2.52 \mathrm{E}-01$ & $5.30 \mathrm{E}-02$ & $2.27 \mathrm{E}-02$ & $2.36 \mathrm{E}-01$ & - \\
\hline $\mathrm{PO}_{4}^{3-}$ & $2.53 \mathrm{E}-02$ & $2.00 \mathrm{E}-02$ & 8.08E-02 & 4.13E-03 & $1.48 \mathrm{E}-03$ & $1.84 \mathrm{E}-02$ & - \\
\hline $\mathrm{F}^{-}$ & $1.80 \mathrm{E}-02$ & 8.20E-03 & $5.75 \mathrm{E}-02$ & $1.11 \mathrm{E}-03$ & 8.08E-04 & 4.93E-03 & $1.21 \mathrm{E}-04$ \\
\hline Acetate & $3.33 \mathrm{E}-01$ & $1.57 \mathrm{E}-01$ & $1.06 \mathrm{E}+00$ & $5.36 \mathrm{E}-02$ & $2.81 \mathrm{E}-02$ & $2.38 \mathrm{E}-01$ & - \\
\hline Formate & $1.10 \mathrm{E}-01$ & $5.82 \mathrm{E}-02$ & $3.51 \mathrm{E}-01$ & 7.18E-02 & 3.67E-02 & $3.20 \mathrm{E}-01$ & - \\
\hline MSA & $1.47 \mathrm{E}-02$ & $1.77 \mathrm{E}-03$ & $4.68 \mathrm{E}-02$ & $1.54 \mathrm{E}-02$ & $1.47 \mathrm{E}-03$ & $6.85 \mathrm{E}-02$ & - \\
\hline $\mathrm{nssCa}^{2+}$ & $1.47 \mathrm{E}-01$ & $1.14 \mathrm{E}-01$ & 4.68E-01 & 4.16E-02 & $3.13 \mathrm{E}-02$ & $1.85 \mathrm{E}-01$ & - \\
\hline $\mathrm{nssK}^{+}$ & 7.14E-02 & $3.11 \mathrm{E}-02$ & $2.28 \mathrm{E}-01$ & $1.30 \mathrm{E}-02$ & $5.28 \mathrm{E}-03$ & 5.78E-02 & - \\
\hline $\mathrm{nssSO}_{4}^{2-}$ & $5.80 \mathrm{E}-01$ & 4.32E-02 & $1.85 \mathrm{E}+00$ & 4.77E-01 & 2.01E-02 & $2.12 \mathrm{E}+00$ & - \\
\hline
\end{tabular}

but that depletion was in the 0.56-5.6 $\mu \mathrm{m}$ range (and also at $<0.056 \mu \mathrm{m}$ ) for period $\mathrm{E}$. This is consistent with the size distributions of $\mathrm{Na}^{+}, \mathrm{Mg}^{2+}$, etc.

The $\mathrm{K}^{+} / \mathrm{Na}^{+}$mass ratio was 0.27 during period $\mathrm{C}$, greater than the sea water value. However, since the contribution of seasalt $\mathrm{K}^{+}$was $39 \%$ of the total concentration of $\mathrm{K}^{+}$during period $\mathrm{E}$, the mass ratio $\mathrm{K}^{+} / \mathrm{Na}^{+}$during this period was reduced to 0.09 , which is close to the seawater value. The peak around $0.18-0.32 \mu \mathrm{m}$ in sample $\mathrm{C}$, along with the higher $\mathrm{nssK}^{+}$fraction for sample $\mathrm{C}$ as opposed to sample $\mathrm{E}$, is consistent with the conclusion in Sect. 5.1 of a non-mineral contribution in that range. While there is no direct evidence of $\mathrm{K}^{+}$from biomass burning sources, we can speculate that on some occasions dust devils may pass over old biomass burning vegetation ash, and thus some of this ash will be mixed with dust particles. In addition, as already noted, there was some air mass advection from the north during period $\mathrm{C}$, which is a biomass burning region at this time of year. The other probable source of soluble $\mathrm{K}^{+}$in these samples is the halides which naturally accumulate in playa regions such as the Lake Eyre Basin. Overall we can conclude that the total potassium found in the Birdsville atmosphere has contributions from a number of sources, including crustal salts, sea spray, and, in the case of period $\mathrm{C}$, biomass burning.

\section{5 $\mathrm{SO}_{4}^{2-}, \mathrm{NH}_{4}^{+}$and Methanesulfonate (MSA)}

Sulfate exists in the coarse fraction as gypsum in soil dust particles, and as $\mathrm{Na}_{2} \mathrm{SO}_{4}$ in sea salt. The source of fine mode $\mathrm{SO}_{4}^{2-}$ over land is industrial pollution and motor vehicle emissions, while marine biogenic emission is the dominant source of fine $\mathrm{nsSO}_{4}^{2-}$ over the ocean. The strong similarity in the $\mathrm{SO}_{4}^{2-}$ and MSA size distributions suggests that the marine contribution was significant at our site. (None of the back trajectories go close enough to Mt Isa to consider it a major source on these two days.)

The total concentrations of $\mathrm{SO}_{4}^{2-}$ were 0.66 and $0.53 \mu \mathrm{g} / \mathrm{m}^{3}$ during periods $\mathrm{C}$ and $\mathrm{E}$, respectively, which is the highest (mass) concentration found among the water-soluble ions in our samples. $85 \%$ and $90 \%$ of those concentrations, respectively, was associated with the fine fraction (Table 4 and Fig. 11). $88 \%$ and $89 \%$ of total $\mathrm{SO}_{4}^{2-}$ was found to be $\mathrm{nssSO}_{4}^{2-}$ for periods $\mathrm{C}$ and $\mathrm{E}$, respectively. The $\mathrm{nssSO}_{4}^{2-}$ size pattern followed the $\mathrm{SO}_{4}^{2-}$ pattern in the entire region $\leq 0.56 \mu \mathrm{m}$, but in the coarse mode the $\mathrm{nssSO}_{4}^{2-}$ is depleted. It has been reported (Saltzman et al., 1983; Huebert et al., 1993; Quinn et al., 1993; Gao et al., 1996) that the majority of $\mathrm{nsSO}_{4}^{2-}$ aerosol particles collected near coastal regions have a size range $0.35-0.7 \mu \mathrm{m}$ in diameter. This fine mode $\mathrm{nssSO}_{4}^{2-}$ is a feature of gas-to-particle conversion (Fitzgerald, 1991). 
The total concentrations of $\mathrm{NH}_{4}^{+}$measured during these sampling periods were 0.22 and $0.73 \mu \mathrm{g} / \mathrm{m}^{3}$, with $85 \%$ and $95 \%$ of those concentrations in the fine fraction for periods $\mathrm{C}$ and $\mathrm{E}$, respectively. The $\mathrm{NH}_{4}^{+}$size distribution is similar to the $\mathrm{SO}_{4}^{2-}$ and MSA size distributions. Ammonia gas reacts with sulphuric acid, and reactive sulphates, to form species in the ammonium sulphate family: $\mathrm{NH}_{4} \mathrm{HSO}_{4} ;\left(\mathrm{NH}_{4}\right)_{2} \mathrm{SO}_{4}$; and metal ammonium sulphates. For a remote, non-industrial location such as our sampling site, sulphuric acid concentrations are likely to be quite low, so that $\left(\mathrm{NH}_{4}\right)_{2} \mathrm{SO}_{4}$ is the most likely of these species. Kadowaki (1976) showed that if the size distribution of sulfate follows the size distribution of $\mathrm{NH}_{4}^{+}$then this indicates the presence of $\left(\mathrm{NH}_{4}\right)_{2} \mathrm{SO}_{4}$ in the air: studies by Kulshrestha et al. (1998), Zhuang et al. (1999) and Parmar et al. (2001) support this argument. Overall, the similarity of the size distributions of $\mathrm{NH}_{4}^{+}$and $\mathrm{SO}_{4}^{2-}$ indicates that $\left(\mathrm{NH}_{4}\right)_{2} \mathrm{SO}_{4}$ was present in the fine fraction in the Birdsville atmosphere during the sampling period. (The mass ratios support this conclusion.)

The oxidation of dimethylsulfide (DMS) is believed to be the source of methanesulfonate (MSA) and $\mathrm{nssSO}_{4}^{2-}$ over the ocean (Bates et al., 1987; Leck and Rodhe, 1991). The total atmospheric concentrations of MSA during both sampling periods was $0.015 \mu \mathrm{g} / \mathrm{m}^{3}$, which is quite close to the value of $0.017 \mu \mathrm{g} / \mathrm{m}^{3}$ found at Cape Grim in Tasmania (Ayers et al., 1986). $88 \%$ and $90 \%$ of this amount was in the fine mode for periods $\mathrm{C}$ and $\mathrm{E}$, respectively. The size distribution of MSA is dominated by the fine fraction, in the range $<0.32 \mu \mathrm{m}$ in diameter for both samples (Fig. 11). This distribution is quite similar to that of $\mathrm{nssSO}_{4}^{2-}$.

Results from cascade impactors at a coastal area of the China Sea have shown that $\mathrm{nsSO}_{4}^{2-}$ and MSA have similar size distributions in the fine mode (particles $\leq 0.5 \mu \mathrm{m}$ ) (Gao et al., 1996). In addition, the size distribution of MSA in this study is consistent with that observed in the atmosphere of US coastal regions (Saltzman et al., 1983, Quinn et al., 1993). The mass ratios of the $\mathrm{nssSO}_{4}^{2-}$ to MSA during the sampling periods were 39.5 and 31 , which is greater by factor of 2 than the values observed at American Samoa of $18.1 \pm 0.9$ (Savoie et al., 1994) and over the North Atlantic Ocean islands $19.6 \pm 2.1$ (Savoie et al., 2002). On the other hand, those ratios are much lower than that obtained over the China Sea, which ranged from 60 to 870 , as a result of $\mathrm{nssSO}_{4}^{2-}$ input from anthropogenic sources (Gao et al., 1996), and over coastal regions in Asia (480 for Hong Kong, and 580 for Taiwan) (Arimoto et al., 1996).

We calculated the concentration of nssSO ${ }_{4}^{2-}$ from nonbiogenic sources by using the following equation (Arimoto et al., 1996)

nonbiogenic nssSO ${ }_{4}^{2-}=$ totalnssSO ${ }_{4}^{2-}-(\mathrm{MSA} \cdot 16)$

The constant 16 represents the ratio of biogenic $\mathrm{nsSSO}_{4}^{2-}$ to MSA found at Cape Grim, Australia by Ayers et al. (1986). This showed that $60 \%$ and $48 \%$ of the $\mathrm{nssSO}_{4}^{2-}$ was found to be nonbiogenic during periods $\mathrm{C}$ and $\mathrm{E}$, respectively. Overall our results suggest that of the total $\mathrm{nsSSO}_{4}^{2-}$ found in this study, continental emissions and marine biogenic activity made similar contributions.

\section{$7 \quad$ Discussion and conclusions}

Birdsville is an ideal location for the study of Australian continental aerosol, and especially mineral dust: in the centre of the Lake Eyre Basin, and often downwind of both mineral dust source regions, and biomass burning regions. We have found clear signatures of both aerosol types in our analysis, as well as clear evidence of the advection of marine aerosol including not only salts, but MSA and related biogenic oxidation products.

Our analysis of AERONET data has shown that around $80 \%$ of the daily mean AOD were below 0.1 for the measurements collected over 3 years, with a moderate annual cycle and a mean of $0.06 \pm 0.03$. There is a stronger seasonal cycle in the Angstrom exponent, with $77 \%$ of daily means in the $0.4-1.6$ range and an annual mean of $0.9 \pm 0.3$. Seasonal average volume size distributions show that summer and spring have maximum aerosol content with coarse mode peaking at $3.85 \mu \mathrm{m}$ radius for both seasons, while during spring there was a fine mode peak with radius range between 0.11 and $0.15 \mu \mathrm{m}$, which is evidence of a second aerosol source: almost certainly biomass burning.

We collected size-resolved aerosol samples over four days in early November, 2006, and subjected them to a range of analyses. The mass distributions show that $\mathrm{PM}_{1}$ accounts for around one third, and $\mathrm{PM}_{2.5}$ around half of the aerosol in the Birdsville atmosphere at this time.

We believe that the picture these samples have presented can be considered typical for the region, although more sampling is required, especially in other parts of the Australian interior, before a more general picture can emerge. There is good consistency - although based on just a few sample sets - between MOUDI-derived size distributions and AERONET distributions. These distributions are also consistent with the generic Australian size distributions obtained by Qin and Mitchell (2009).

Ion beam analysis was used primarily to study the mass ratios of crustal (and some other) elements to silicon. A number of elements were well correlated with $\mathrm{Si}$ over all size fractions, especially $\mathrm{Fe}, \mathrm{Al}$ and $\mathrm{Ti}$. Ca and Mn showed two populations, with one clearly correlated with $\mathrm{Si}$. Other elements showed a weaker correlation. Potassium also showed clear evidence of two populations, one well correlated with $\mathrm{Si}$, and hence presumably crustal, and one not, and most likely of biomass burning origin. For those elements that are well correlated with $\mathrm{Si}$ - including some with more than one population - the regression slope (Fig. 9) may be included as part of a desert dust signature for this region of Australia. 
Table 5. Ratios of Fe to Al.

\begin{tabular}{lll}
\hline Sampling site & Fe/Al & Reference \\
\hline Birdsville-Australia & $0.77-0.85$ & this study \\
Southwestern United States & 0.6 & Cahille et al. (1986) \\
Shaartuz-Tadzhikistan & 0.4 & Gomes and Gillette (1993) \\
Zhenbeitai-China & 0.6 & Lafon et al. (2006) \\
Harmattan-Niger & 0.43 & Lafon et al. (2006) \\
Cape Verde-Central Sahara & 0.45 & Lafon et al. (2006) \\
Sal Island & $0.51-0.54$ & Chiapello et al. (1997) \\
Beijing-China & $0.55-0.6$ & Sun et al. (2005) \\
Chinese Desert Regions & $0.25-1.2$ & Zhang et al. (1997) \\
\hline
\end{tabular}

The Fe/Si mass ratio was moderately higher than the value in the Earth's crust in all events, indicating that the soil source of these particles in the Australian arid region is rich in $\mathrm{Fe}$. In turn, the Fe/Al mass ratio was found to be in the range $0.77-0.85$, which is moderately higher than the values reported in the literature for other parts of the world (typically 0.4-0.6): see Table 5. While Fe is found in a number of different minerals (results of a mineralogical analysis, to be presented elsewhere), it is highly likely that this reflects a correspondingly higher fraction of iron oxide minerals such as hematite, by comparison with the Northern Hemisphere. This is consistent with the finding by Qin and Mitchell (2009) who reported enhanced hematite in Australian dust, with their dust aerosol class exhibiting strong absorption in the blue, a characteristic of hematite.

$\mathrm{The} \mathrm{Na} / \mathrm{Cl}$ mass ratio of 0.38 is greater than the values in Earth's crust, which is a reflection of the dry lakes which are widespread in the Australian arid region, so that dry salts are well mixed with mineral dust. The analysis of watersoluble ions found that the $\mathrm{Na}^{+} / \mathrm{Cl}^{-}$mass ratio was 0.44 (for sample period $\mathrm{C}$ ), which is close to the values found in the IBA results, supporting our conclusion that dry salt is well mixed with mineral aerosols in the Australian arid region.

Analysis of soluble ions showed that $\mathrm{Na}^{+}, \mathrm{Cl}^{-}, \mathrm{Mg}^{2+}$, $\mathrm{Ca}^{2+}$ and $\mathrm{NO}_{3}^{-}$have similar size distributions, peaking in the lower coarse mode. For most of these ions a common source, such as sea spray, can be reasonably assumed. (Apart from moderately soluble gypsum, mineral dust $\mathrm{Ca}$ is largely insoluble. Reaction (R5) may also produce soluble Ca.) The chemical reactions discussed in Sect. 6.3 would help to link these distributions. We also note that the sea salt fraction of $\mathrm{K}^{+}$is largely found in the same size range as these sea water ions.

Water-soluble analysis (ion chromatography) shows that $\sim 85 \%$ of $\mathrm{SO}_{4}^{2-}$ was associated with particles $\leq 0.56 \mu \mathrm{m}$ in diameter, and $88 \%$ of total $\mathrm{SO}_{4}^{2-}$ was found to be $\mathrm{nssSO}_{4}^{2-}$, and depletion occurred mainly in the coarse fraction. In addition, the size distribution of MSA follows that of $\mathrm{nsSSO}_{4}^{2-}$, with maximum concentration $(88 \%)$ again allied with particles $\leq 0.56 \mu \mathrm{m}$ in diameter. In addition, the mass ratio of
$\mathrm{nssSO}_{4}^{2-}$ to MSA, which was 31-39.5, suggests a large input of marine biogenic emission to atmospheric $\mathrm{nssSO}_{4}^{2-}$ over the Australian arid region. $\mathrm{The}^{\mathrm{NH}}+$ concentration was dominated by particles with diameter $\leq 0.56 \mu \mathrm{m}$, with the size distribution again following the $\mathrm{nssSO}_{4}^{2-}$ pattern, which strongly suggests that $\left(\mathrm{NH}_{4}\right)_{2} \mathrm{SO}_{4}$ is present in the fine fraction in this region.

From our analyses, the following picture of aerosol in the Birdsville area emerges. The size distribution can be considered bimodal for our purposes. The fine mode is strongly influenced by biomass burning in spring, plus some fine dust, but also has a significant contribution of marine biogenic origin whenever the air mass has recently passed over the ocean. The coarse mode is dominated by crustal elements, with a higher than average iron content. There is also an important contribution from halide elements, either from dry lakes or the sea-most likely both.

Acknowledgements. This work was supported by Australian Research Council Grant DP0451400. Ion Beam Analysis was performed under AINSE Grant AINGRA08006. Additional support was provided jointly by the Department of Climate Change, the Bureau of Meteorology and CSIRO as part of the Australian Climate Change Science Program.

Edited by: U. Baltensperger

\section{References}

Arimoto, R., Duce, R. A., Savoie, D. L., Prospero, J. M., Talbot, R., Cullen. J. D., Tomza, U., Lewis, N. F., and Ray, B. J.: Relationships among aerosol constituents from Asia and the North Pacific during PEMWest A, J. Geophys. Res., 101, 2011-2023, 1996.

Ayers, G. P., Ivey, J. P., and Goodman, H. S.: Sulfate and Methanesulfonate in the maritime aerosol at Cape Grim, Tasmania, J. Atmos. Chem., 4, 173-185, 1986.

Bates, T. S., Cline, J. D., Gammon, R. H., and Kelly-Hansen, S. R.: Regional and seasonal variations in the flux of oceanic dimethylsulfide to the atmosphere, J. Geophys. Res., 92, 2930-2938, 1987.

Boon, K. F., Kiefert, L., and McTainsh, G. H.: Organic matter content of rural dusts in Australia, Atmos. Environ., 32, 2817-2823, 1998.

Bullard, J. E. and White, K.: Quantifying iron oxide coatings on dune sands using spectrometric measurements: An example from the Simpson-Strzelecki Desert, Australia, J. Geophys. Res., 107(B6), 2125, doi:10.1029/2001JB000454, 2002.

Bullard, J. E., Baddock, M., McTainsh, G. H., and Leys, J. F.: Subbasin scale dust source geomorphology detected using MODIS, Geophys. Res. Letts., 35, L15404, doi:10.1029/2008GL033928, 2008.

Cahille, T., Eldred, R., and Feeney, P.: Particulate monitoring and data analysis for the National Park Service, 1982-1985, in: National Park Service Contract Number USDICX-0001-3-0056, Malm, W., Project Manager, 1986. 
Charlson, R. J., Schwartz, S. E., Hales, J. M., Cess, R. D., Coakley, J. A., Hansen, J. E., and Hofmann, D. J.: Climate forcing by anthropogenic aerosols, Science, 255, 423-430, 1992.

Chiapello, I., Bergametti, G., Chatenet, B., Bousquet, P., Dulac, F., and Soares, E.: Origins of African dust transported over the northeastern tropical Atlantic, J. Geophys. Res., 102, 1370113709, 1997.

Cohen, D. D.: Applications of simultaneous IBA techniques to aerosol analysis, Nucl. Instr. Meth., B79, 385-388, 1993.

Cohen, D. D.: Characterisation of atmospheric fine particles using IBA techniques, Nucl. Instr. Meth., B136, 14-22, 1998.

Cohen, D. D., Graham, M. B., and Kondepudi, R..: Elemental analysis by PIXE and other IBA techniques and their application to source fingerprinting of atmospheric fine particle pollution, Nucl. Instr. Meth., B109-110, 218-226, 1996.

Cohen, D. D., Siegele, R., Ivo, O., and Stelcer, E.: Long-term accuracy and precision of PIXE and PIGE measurements for thin and thick sample analyses, Nucl. Instr. Meth., B189, 81-85, 2002.

Dasch, J. M. and Cadle, S. H.: The removal of nitric acid to atmospheric particles during a wintertime field study, Atmos. Environ., 24A, 2557-2562, 1990.

Dentener, F. J., Carmichael, G. R., Zhang, Y., Lelieveld, J., and Crutzen, P. J.: Role of mineral aerosol as a reactive surface in the global troposphere, J. Geophys. Res., 101, 22869-22889, 1996.

Dubovik, O., Holben, B., Eck, T. F., Smirnov, A., Kaufman, Y. J., King, M. D., Tanré, D., and Slutsker, I.: Variability of absorption and optical properties of key aerosol types observed in worldwide locations, J. Atmos. Sci., 59, 590-608, 2002.

Dubovik, O. and King, M. D.: A flexible inversion algorithm for retrieval of aerosol optical properties from Sun and sky radiance measurements, J. Geophys. Res., 105, 20673-20696, 2000.

Eck, T. F., Holben, B. N., Reid, J. S., Sinyuk, A., Dubovik, O., Smirnov, A., Giles, D., O’Neill, N. T., Tsay, S.-C., Ji, Q., Al Mandoos, A., Ramzan Khan, M., Reid, E. A., Schafer, J. S., Sorokine, M., Newcomb, W., and Slutsker, I.: Spatial and temporal variability of column-integrated aerosol optical properties in the southern Arabian Gulf and United Arab Emirates in summer, J. Geophys. Res., 113, D01204, doi:10.1029/2007JD008944, 2008.

Fitzgerald, J. W.: Marine aerosols: A review, Atmos. Environ., 25, 533-545, 1991.

Forster, P., Ramaswamy, V., Atraxo, P., Bernsten, T., Betts, R., Fahey, D., Haywood, J., Lean, J., Lowe, D., Myhre, G., Nganga, J., Prinn, R., Raga, G., Schulz, M., and Dorland, R. V.: Changes in Atmospheric Constituents and in Radiative Forcing, in: Climate Change 2007: The Physical Science Basis, Contribution of Working Group I to the Fourth Assessment Report of the Intergovernmental Panel on Climate Change, Cambridge University Press, Cambridge, United Kingdom and New York, NY, USA, edited by: Solomon, S., Qin, D., Manning, M., Chen, Z., Marquis, M., Averyt, K. B., Tignor, M., and Miller, H. L., 2007.

Gao, Y., Arimoto, R., Duce, R. A., Chen, L. Q., Zhou, M. Y., and $\mathrm{Gu}, \mathrm{D}$. Y.: Atmospheric non-sea-salt sulfate, nitrate and methanesulfonate over the China Sea, J. Geophys. Res., 101(D7), 12601-12611, 1996.

Gloudemans, A. M. S., Krol, M. C., Meirink, J. F., de Laat, A. T. J., van der Werf, G. R., Schrijver, H., van den Broek, M. M. P., and Aben, I.: Evidence for long-range transport of carbon monoxide in the Southern Hemisphere from Sciamachy observations,
Geophys. Res. Lett., 33, L16807, doi:10.1029/2006GL026804, 2006.

Gomes, L. and Gillette, D. A.: A comparison of characteristics of aerosol from dust storms in Central Asia with soil-derived dust from other regions, Atmos. Environ., 27, 2539-2544, 1993.

Greene, R. S. B., Cattle, S. R. and McPherson, A. A.: Role of eolian deposits in landscape development and soil degradation in southeastern Australia, Aust. J. Earth Sciences, 56, 55-65, 2009.

Harrison, R. M. and Pio, C. A.: Size-differentiated composition of inorganic atmospheric aerosols of both marine and polluted continental origin, Atmos. Environ., 17, 1733-1783, 1983.

Holben, B. N., Eck, T. F., Slutsker, I., Tanre, D., Buis, J. P., Setzer, A., Vermote, E., Reagan, J. A., Kaufman, Y. J., Nakajima, T., Lavenu, F., Jankowiak, I., and Smirnov, A.: AERONET - A federated instrument network and data archive for aerosol characterization, Remote Sens. Environ., 66, 1-16, 1998.

Huebert, B. J., Howell, S., Laj, P., Johnson, J. E., Bates, T. S., Quinn, P. K., Yegorov, V., Clarke A. D., and Porter, J. N.: Observations of the atmospheric sulfur cycle on SAGA 3, J. Geophys. Res., 98, 16985-16995, 1993.

Jacob, D. J.: Heterogeneous chemistry and tropospheric ozone, Atmos. Environ., 34, 2131-2159, 2000.

John, W., Wall, S. M., Ondo, J. L., and Winklmayr, W.: Modes in the size distributions of atmospheric inorganic aerosol, Atmos. Environ., 24A, 2349-2359, 1990.

Kadowaki, S.: Size distribution of atmospheric total aerosols, sulfate, ammonium and nitrate particulate in the Nagoya area, Atmos. Environ., 10, 39-43, 1976.

Keywood, M. D., Ayers, G. P., Gras, J. L., Gillett, R. W., and Cohen, D. D.: Relationships between size segregated mass concentration data and ultrafine particle number concentrations in urban areas, Atmos. Environ., 33, 2907-2913, 1999.

Kiefert, L., McTainsh, G. H., and Nickling, W. G.: Sedimentological characteristics of Saharan and Australian dusts, in The Impact of Desert Dust Across the Mediterranean, edited by: Guerzoni, S. and Chester, R., 183-190, 1996.

Kubilay, N., Cokacar, T., and Oguz, T.: Optical properties of mineral dust outbreaks over the northeastern Mediterranean, J. Geophys. Res., 108(D21), 4666, doi:10.1029/2003JD003798, 2003.

Kulshrestha, U. C., Saxena, A., Kumar, N., Kumari, K. M., and Srivastava, S. S.: Chemical composition and association of sizedifferentiated aerosols at a suburban site in a semi-arid tract of India, J. Atmos. Chem., 29, 109-118, 1998.

Lafon, S., Sokolik, I. N., Rajot, J. L., Caquineau, S., and Gaudichet, A.: Characterization of iron oxides in mineral dust aerosols: Implications for light absorption, J. Geophys. Res., 111, D21207, doi:10.1029/2005JD007016, 2006.

Leck, C. and Rodhe, H.: Emissions of marine biogenic sulfur to the atmosphere of northern Europe, J. Atmos. Chem., 12, 63-86, 1991.

Lide, D. R. (Ed.): CRC Handbook of Chemistry and Physics, 78th edition, CRC Press, Boca Raton, FL, USA, 1997.

McTainsh, G. H.: Quarternary aeolian dust processes and sediments in the Australian region, Quarternary Sci. Rev., 8, 235253, 1989.

Mays, M. D., Nettleton, W. D., Greene, R. S. B., and Mason, J. A.: Dispersibility of glacial loess in particle size analysis, USA, Aust. J. Soil Res., 41, 229-244, 2003.

Mamane, Y. and Gottlieb, J.: Nitrate formation on sea-salt and min- 
eral particles a single particle approach, Atmos. Environ., 26A, 1763-1769, 1992.

Marple, V. A., Rubow, K. L., and Behm, S. M.: A Micro-Orifice Uniform Deposit Impactor (MOUDI): Description, calibration and use, Aerosol Sci, Tech., 14, 434-446, 1991.

Millero, F. J. and Sohn, M. L.: Chemical Oceanography, CRC Press, Boca Raton, FL, USA, 1992.

Mitchell, R. M. and Forgan, B. W.: Aerosol measurement in the Australian outback: intercomparison of sun photometers, J. Atmos. Ocean. Tech., 20, 54-66, 2003.

Mitchell, R. M., Campbell, S. K., and Qin Y.: Recent increase in aerosol loading over the Australian arid zone, Atmos. Chem. Phys., 10, 1689-1699, doi:10.5194/acp-10-1689-2010, 2010.

Nishikawa, M., Kanamori, S., Kanamori, N., and Mizoguchi, T.: Kosa aerosol as eolian carrier of anthropogenic material, Sci. Total Environ., 107, 13-27, 1991.

Pakkanen, T. A., Kerminen, V. M., Hillamo, R. E., Makinen, M., Makela, T. and Virkkula, A.: Distribution of nitrate over sea-salt and soil derived particles - implications from a field study, J. Atmos. Chem., 24, 189-205, 1996.

Parmar, R. S., Satsangi, G. S., Kumari, M., Lakhani, A., Srivastava, S. S., and Prakash, S.: Study of size distribution of atmospheric aerosol at Agra, Atmos. Environ., 35, 693-702, 2001.

Prospero, J. M. and Savoie, D. L.: Effect of continental sources of nitrate concentrations over the Pacific Ocean, Nature, 33, 687689, 1989.

Qin, Y. and Mitchell, R. M.: Characterisation of episodic aerosol types over the Australian continent, Atmos. Chem. Phys., 9, 1943-1956, doi:10.5194/acp-9-1943-2009, 2009.

Quinn, P. K., Covert, D. S., Bates, T. S., Kapustin, V. N., RamseyBell, D. C., and McInnes, L. M.: Dimethylsulfide/cloud condensation nuclei/climate system: Relevant size-resolved measurements of the chemical and physical properties of atmospheric aerosol particles, J. Geophys. Res., 98, 10411-10427, 1993.

Ramanathan, V., Crutzen, P., J., Kiehl, J. T., and Rosenfeld, D.: Aerosols, climate, and the hydrological cycle, Science, 294, 2119-2124, 2001.

Reid, J. S., Jonsson, H. H., Maring, H. B., Smirnov, A., Savoie, D. L., Cliff, S. S., Reid, E. A., Livingston, J. M., Meier, M. M., Dubovik, O., and Tsay, S.-C.: Comparison of size and morphological measurements of coarse mode dust particles from Africa, J. Geophys. Res., 108(D19), 8593, doi:10.1029/2002JD002485, 2003.

Rosen, J. M., Young, S. A., Laby, J., Kjome, N., and Gras, J.: Springtime aerosol layers in the free troposphere over Australia: Mildura Aerosol Tropospheric Experiment (MATE 98), J. Geophys. Res., 105, 17833-17842, 2000.

Saltzman, E. S., Savoie, D. L., Zika, R. G., and Prospero, J. M.: Methanesulphonic acid in the marine atmosphere, J. Geophys. Res., 88, 10897-10902, 1983.
Savoie, D. L. and Prospero, J. M.: Particle size distribution of nitrate and sulfate in the marine atmosphere, Geophys. Res. Lett., 9, 1207-1210, 1982.

Savoie, D. L., Prospero, J. M., Arimoto, R., and Duce, R. A.: Nonseasalt sulfate and methanesulfonate at American Samoa, J. Geophys. Res., 99, 3587-3596, 1994.

Savoie, D. L., Arimoto, R., Keene, W. C., Prospero, J. M., Duce, R. A., and Galloway, J. N.: Marine biogenic and anthropogenic contributions to non-sea-salt-sulfate in the marine boundary layer over the North Atlantic Ocean, J. Geophys. Res., 107(D18), 4356, doi:10.1029/2001JD000970, 2002.

Sokolik, I. N. and Toon, O. B.: Direct radiative forcing by anthropogenic airborne mineral aerosols, Nature, 381, 681-683, 1996.

Sokolik, I. N., Winker, D. M., Bergametti, G., Gillette, D. A., Carmichael, G., Kaufman, Y. J., Gomes, L., Schuetz, L., and Penner, J. E.: Introduction to special section: outstanding problems in quantifying the radiative impacts of mineral dust, J. Geophys. Res., 106, 18015-18027, 2001.

Sun, Y., Zhuang, G., Wang, Y., Zhao, X., Li, J., Wang, Z., and An, Z.: Chemical composition of dust storms in Beijing and implications for the mixing of mineral aerosol with pollution aerosol on the pathway, J. Geophys. Res., 110, D24209, doi:10.1029/2005JD006054, 2005.

Tanaka, T. Y. and Chiba, M.: A numerical study of the contributions of dust source regions to the global dust budget, Glob. Planet. Change, 52, 88-104, 2006.

Tegen, I., Lacis, A. A., and Fung, I.: The influence on climate forcing of mineral aerosols from disturbed soils, Nature, 380, 419422, 1996.

Weinzierl, B., Petzold, A., Esselborn, M., Wirth, M., Rasp, K., Kandler, K., Schutz, L., Koepke, P., and Fiebig, M.: Airborne measurements of dust layer properties, particle size distribution and mixing state of Saharan dust during SAMUM 2006, Tellus, 61B, 96-117, 2008.

Wolf, G. T.: On the nature of nitrate in coarse continental aerosols, Atmos. Environ., 18, 977-981, 1984.

Wall, S. M., John, W., and Ondo, J. L.: Measurement of aerosol size distributions for nitrate and major ionic species, Atmos. Environ., 22, 1649-1656, 1988.

Zhang, X. Y., Arimoto, R., and An, Z.: Dust emission from Chinese desert sources linked to variations in atmospheric circulation, J. Geophys. Res., 102, 28041-29047, 1997.

Zhuang, H., Chan, C. K., Fang, M., and Wexler, A. S.: Size distributions of particulate sulfate, nitrate, and ammonium at a coastal site in Hong Kong, Atmos. Environ., 33, 843-853, 1999. 